$\frac{333 / 169}{816}$ LA-7674-MS

Informal Report

MASTER

Gas Generation from Radiolytic Attack of TRU-Contaminated Hydrogenous Waste 
LA.7674-MS

Informal Report

vC.70

Imared: June 1979

\title{
Gas Generation from Radiolytic Attack of TRU-Contaminated Hydrogenous Waste
}

\author{
Al Zerwekh
}

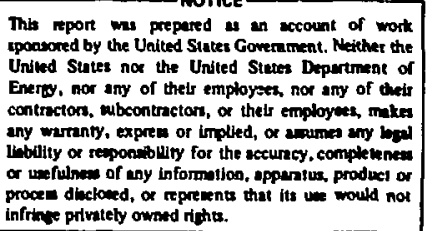




\title{
GAS GENERATION FROM RADIOLYTIC ATTACK OF TRU-CONTAMINATED HYDROGENOUS WASTE
}

\author{
by
}

\author{
Al Zerwekh
}

\begin{abstract}
In 1970, the Waste Management and Transportation Division of the Atomic Energy Commission ordered a segregation of transuranic (TRU)contaminated solid wastes. Those below a contamination level of $10 \mathrm{nCi} / \mathrm{s}$ could still be buried; those above had to be stored retrievably for $20 \mathrm{yr}$. The possibility that alpha-radiolysis of hydrogenous materials might produce toxic, corrosive, and flammable gases in retrievably stored wante prompted an investigation of gas identities and generation rates in the laboratory and field. Typical waste mixtures were synthesized and contaminated for laboratory experiments, and drums of actual TRU-contaminated waste werc instrumented for field testing. Several levels of contamination were studied, as well as pressure, temperature, and moisture effects. G(gas) values were determined for various waste matrices, and degradation products were examined.
\end{abstract}

\section{INTRODUCTION}

In 1970, the Waste Management and Transportation Division of the Atomic Energy Commission (AEC) issued an Immediate Action Directive specifying that solid waste contaminated with ${ }^{235} U$ and its daughter products, plutonium, and transplutonium nuclides (except ${ }^{280} \mathrm{Pu}$ and ${ }^{201} \mathrm{Pu}$ ) could continue to be buried at AEC-approved sites if their radioactivity levels did not exceed $10 \mathrm{nCi} / \mathrm{g}$ of waste matrix. Plutonium-238 and plutonium-241 were to be handled as transuranic radionuclides (TRU) when so indicated by ${ }^{230} \mathrm{Pu}$ impurities or when required by local burial criteria. Solid wastes contaminated at $\geq 10 \mathrm{nCi} / \mathrm{g}$ could no longer be buried, but would be stored at AEC sites, segregated from other radioactively contaminated solid waste, with combustible and noncombustible TRUcontaminated waste packaged separately. The packaging and storing conditions must allow the packages to be retrieved readily for $20 \mathrm{yr}$ in an intact, contamination-free condition. ${ }^{2}$

It was suspected that alpha radiolysis of cellulosic and plastic materials could produce toxic, corrosive, and flammable gases." The presence, or subsequent chemical reactions, of these gases could violate the "intact, contamination-free condition" criterion. However, disagreement on the theoretical magnitude of the gas generation problem did exist." Consequently, an investigation was undertaken to determine actual gas generation rates by laboratory and field experiments. 


\section{HISTORY}

Characteristically, the TRU elements are longlived (half-lives measured in thousands of years) and decay by emitting discrete energy alpha particles, ganma quanta, and $x$ rays. Because the alpha particles carry practically all the decay energy, the radiolysis effects of gamma and $x$ rays will be significant. Figure 1 provides simplified decay schemes for all TRU elements expected in contaminated solid wastes.

Only rarely will a single plutonium isotope be encountered in solid waste. Table I shows that a mixture of plutonium isotopes will be present. If the percentage of ${ }^{21} \mathrm{Pu}$ is appreciable, as for reactorproduced plutonium, and the plutonium is more than $1 \mathrm{vr}$ old, significant concentrations of ${ }^{2+1} \mathrm{Am}$ will have grown in. The specific activity of a given radioisotope depends upon its half-life. The specific activities of various TRU nuclides, daughters, and plutonium mixtures are given in Table II.

Most of the early radiation chemistry research involved the radiolysis of water, dilute salt solutions, or gaseous mixtures, using the alpha particles released by the decay of radium and radon. ${ }^{5}$ In recent years, a more direct interest in alpha radiolysis has arisen because of the increasing volumes of stored solid hydrogenous wastes contaminated with TRLi elements. The waste matrices result from the large quantities of cellulosic wiping materials, discarded laboratory clothing, and rubber gloves used in TRU facilities.

Typically, an average of $34 \mathrm{~kg}$ of wastes are packaged and stored in $210-\ell$ mild steel drums fitted with a $2.3-\mathrm{mm} 100 \%$ cross-linked high-density polyet hylene liner. Criticality calculations limit the ${ }^{239} \mathrm{Pu}$ content to $\leq 200 \mathrm{~g}$ per drum. Pashman ${ }^{3}$ concluded that a maximum pressure of $240 \mathrm{kPa}$ could be contained by a typical drum and liner, but that this pressure might be exceeded in $20 \mathrm{yr}$ by a drum containing even less than the $200-\mathrm{g}$ limit if the ${ }^{230} \mathrm{Pu}$ were distributed evenly in the waste matrix. Michels ${ }^{4}$ theorized that $\mathrm{H}_{2}$ gas pressure build-up would not be significant. He estimated $<2 \mathrm{kPa}$ in 20 $\mathrm{yr}$ for $200 \mathrm{~g}{ }^{239} \mathrm{Pu}$ in a $210 \cdot \boldsymbol{l}$ drum of contaminated waste sealed for storage. However, no supporting data were available. Mcluain ${ }^{\circ}$ reported $\mathrm{H}_{2}$ concentrations greater than the minimum explosive mixture following exhumation of culverts containing plutonium-contaminated wastes after $5 \mathrm{yr}$. The same report refers to radiolysis studies by Bibler,? which show that a gas mixture of $48-50 \% \mathrm{H}_{2}, 38 \%$ $\mathrm{CO}_{2}$, and $13 \% \mathrm{CO}$ is formed from contaminated cellulosic waste. Various amounts of ${ }^{24} \mathrm{Cm}$ absorbed by paper tissue produced a mixture of $49 \% \mathrm{H}_{2}, 36 \%$ $\mathrm{CO}_{3}$, and $15 \% \mathrm{CO}$ at a rate that would become significant in less than $20 \mathrm{yr}^{7} \mathrm{Kazanjian}^{8}$ ground $1 \mathrm{~g}$ ${ }^{239} \mathrm{Pu}$ oxide with combustible material and observed a build-up of gas pressure in 3 months. Extrapolated to $20 \mathrm{yr}$, the amount of $\mathrm{H}_{2}$ produced would exceed explosive limits in air in a closed storage facility.

Because of the semiqualitative and limited data in these early reports, we decided to establish an array of simulated waste matrices and to introduce known amounts of radioactive contamination. Detailed analyses of the emitted gases would enable more accurate extrapolations to buried and stored wastes.

\section{EXPERIMENTS}

\section{A. Laboratory Array}

The basis chosen for the experimental array would simulate a "maximum allowable" ${ }^{29} \mathrm{Pu}$ loading; that is, $200 \mathrm{~g}{ }^{230} \mathrm{Pu}$ in $34 \mathrm{~kg}$ waste. This level of contamination is equivalent to $4 \times 10^{8} \mathrm{nCi} / \mathrm{g}$ waste. For the laboratory-scale experiments, 300 $\mathrm{cm}^{3}$ stainless steel pressure cylinders were chosen, and each was loeded with $52.5 \mathrm{~g}$ of waste matrix. We assumed that there would be a straight-line relationship between energy input and gas generation. Therefore, we attempted to obtain $20 \mathrm{yr}$ of data in 6 months by increasing the rate of alpha attack by a factor of 40 . To minimize the quantity of radioactive material present., heat source grade $(80 \%){ }^{236} \mathrm{Pu}$ was substituted for weapons grade $(94.5 \%){ }^{230} \mathrm{Pu}$. For each type of waste matrix, there were three different levels of contamination: high, medium, and low. The high level was $62 \mathrm{mg}$ of heat source grade ${ }^{239} \mathrm{Pu}$ in $52.5 \mathrm{~g}$ waste to simulate in 6 months the energy dissipation of $200 \mathrm{~g}{ }^{230} \mathrm{Pu}$ over $20 \mathrm{yr}$. The medium level of contamination was $31 \mathrm{mg}$ of ${ }^{230} \mathrm{Pu}$ in $52.5 \mathrm{~g}$ of matrix; the low was $6.2 \mathrm{mg}$. Each cylinder was equipped with a $103.4-\mathrm{kPa}$ (15-psi) pressure gauge and a valve to allow air-free sampling of the contents. On the basis of waste sorting and categorizing at the Los Alamos Scientific 


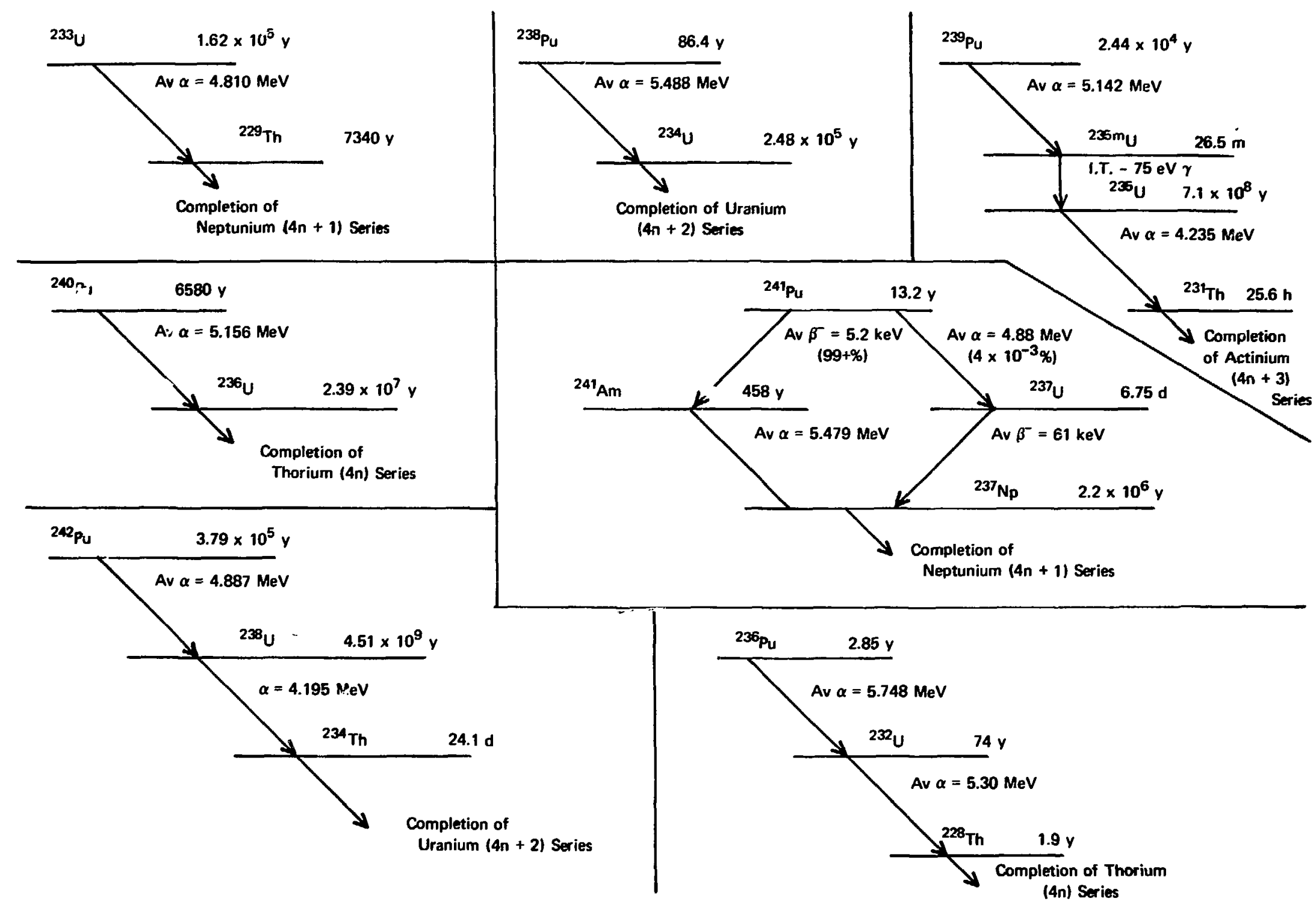

Fig. 1. 
TABLE I

\section{TYPICAL ISOTOPIC COMPOSITION FOR VARIOUS PLUTONIUM TYPES (wt\%)}

\begin{tabular}{|c|c|c|c|c|c|c|c|}
\hline Type & $\begin{array}{c}\text { Burnup } \\
10^{\mathrm{s}} \mathrm{MWD} / \mathrm{T}\end{array}$ & ${ }^{236} \mathbf{P u}$ & ${ }^{230} \mathbf{P u}$ & ${ }^{230} \mathrm{Pu}$ & ${ }^{240} \mathrm{Pu}$ & ${ }^{201} \mathrm{Pu}$ & ${ }^{209} \mathrm{Pu}$ \\
\hline Weapons grade & -. & -- & -- & 94.5 & 5.0 & 0.5 & -- \\
\hline $\begin{array}{l}\text { Pressurized } \\
\text { water } \\
\text { reactor }\end{array}$ & $\begin{array}{l}14.5 \pm 1 \\
24.0 \pm 2 \\
29.5 \pm 1.5 \\
32.5 \pm 0.5\end{array}$ & $\begin{array}{l}5.1 \times 10^{-6} \\
1.2 \times 10^{-5} \\
1.7 \times 10^{-5} \\
2.1 \times 10^{-5}\end{array}$ & $\begin{array}{l}0.42 \\
1.0 \\
1.4 \\
1.7\end{array}$ & $\begin{array}{l}67.0 \\
58.5 \\
56.5 \\
55.5\end{array}$ & $\begin{array}{l}21.7 \\
23.9 \\
23.5 \\
24.3\end{array}$ & $\begin{array}{r}9.2 \\
11.9 \\
13.0 \\
13.4\end{array}$ & $\begin{array}{l}2.1 \\
4.4 \\
5.2 \\
5.7\end{array}$ \\
\hline $\begin{array}{l}\text { Boiling } \\
\text { water } \\
\text { reactor }\end{array}$ & $\begin{array}{l}19.0 \pm 1.5 \\
23.0 \pm 0.5 \\
27.0 \pm 1.0 \\
28.0 \pm 1.0\end{array}$ & $\begin{array}{l}8.0 \times 10^{-8} \\
1.1 \times 10^{-6} \\
1.4 \times 10^{-8} \\
1.5 \times 10^{-8}\end{array}$ & $\begin{array}{l}0.9 \\
1.3 \\
1.7 \\
1.8\end{array}$ & $\begin{array}{l}61.7 \\
56.9 \\
52.4 \\
54.2\end{array}$ & $\begin{array}{l}22.4 \\
23.8 \\
25.0 \\
23.8\end{array}$ & $\begin{array}{l}11.3 \\
12.7 \\
13.7 \\
13.5\end{array}$ & $\begin{array}{l}3.4 \\
5.3 \\
6.6 \\
6.4\end{array}$ \\
\hline${ }^{230} \mathrm{Pu}$ fuel & $\cdots$ & $1.0 \times 10^{-8}$ & 80.0 & 16.3 & 3.0 & 0.6 & 0.1 \\
\hline Weapons grade & - & -. & -. & 94.5 & 5.0 & 0.5 & -. \\
\hline $\begin{array}{l}\text { Pressurized } \\
\text { water } \\
\text { reactor }\end{array}$ & $\begin{array}{l}14.5 \pm 1 \\
24.0 \pm 2 \\
29.5 \pm 1.5 \\
32.5 \pm 0.5\end{array}$ & $\begin{array}{l}5.1 \times 10^{-0} \\
1.2 \times 10^{-5} \\
1.7 \times 10^{-5} \\
2.1 \times 10^{-5}\end{array}$ & $\begin{array}{l}0.42 \\
1.0 \\
1.4 \\
1.7\end{array}$ & $\begin{array}{l}67.0 \\
58.5 \\
56.5 \\
55.5\end{array}$ & $\begin{array}{l}21.7 \\
23.9 \\
23.5 \\
24.3\end{array}$ & $\begin{array}{r}9.2 \\
11.9 \\
13.0 \\
13.4\end{array}$ & $\begin{array}{l}2.1 \\
4.4 \\
5.2 \\
5.7\end{array}$ \\
\hline $\begin{array}{l}\text { Boiling } \\
\text { water } \\
\text { reactor }\end{array}$ & $\begin{array}{l}19.0 \pm 1.5 \\
23.0 \pm 0.5 \\
27.0 \pm 1.0 \\
28.0 \pm 1.0\end{array}$ & $\begin{array}{l}8.0 \times 10^{-6} \\
1.1 \times 10^{-5} \\
1.4 \times 10^{-5} \\
1.5 \times 10^{-5}\end{array}$ & $\begin{array}{l}0.9 \\
1.3 \\
1.7 \\
1.8\end{array}$ & $\begin{array}{l}61.7 \\
56.9 \\
52.4 \\
54.2\end{array}$ & $\begin{array}{l}22.4 \\
23.8 \\
25.0 \\
23.8\end{array}$ & $\begin{array}{l}11.3 \\
12.7 \\
13.7 \\
13.5\end{array}$ & $\begin{array}{l}3.4 \\
5.3 \\
6.6 \\
6.4\end{array}$ \\
\hline${ }^{238} \mathrm{Pu}$ fuel & -. & $1.0 \times 10^{-6}$ & 80.0 & 16.3 & 3.0 & 0.6 & 0.1 \\
\hline
\end{tabular}

Laboratory (LASL), the following hydrogenous wastes were chosen for laboratory radiolysis studies.

1. A cellulosics mixture consisting of paper wipes, paper tissues, embossed paper table towel with polyethylene backing (diaper paper), cheesecloth, and cotton laboratory smock material.

2. Hypalon (chlorosulfonated polyethylene) drybox gloves.

3. Isoprene surgical gloves.

4. Polyethylene (low-density) bags, $0.05 \mathrm{~mm}$ thick.

5. Tygon (vinyl chloride-acetate copolymer) tubing.

6. Neoprene drybox gloves.
7. Lucite (methylmethacralate) sheet plastic.

8. Polyvinyl chloride, 0.3-mm-thick bagout material.

9. Vinyl Bakelite, 0.3-mm bagout material.

10. Polyethylene (high-deusity) drum liner material, $2.3 \mathrm{~mm}$ thick.

Each of these materials was cut into pieces approximately 5 by $5 \mathrm{~cm}$, except for the Lucite and Tygon, which were cut 1 by $5 \mathrm{~cm}$, and laid out in a flat array to be contaminated with ${ }^{230} \mathrm{Pu}$ contained in $2 M$ $\mathrm{HNO}_{3}$. The plutonium solution was placed on the pieces with a medicine dropper in as uniform a pattern as possible. Tro material was allowed to dry, and then was loaded into the $300-\mathrm{cm}^{\prime}$ stainless steel cylinders (Fig. 2). A control cylinder was prepared 
TABLE II

\section{SPECIFIC ACTIVITIES OF TRU AND DAUGHTER NUCLIDES}

\begin{tabular}{|c|c|}
\hline Nuclide & $\begin{array}{l}\text { Specific Activity } \\
(\mathrm{Ci} / \mathrm{g}) \\
\end{array}$ \\
\hline${ }^{25 s} \mathrm{U}$ & 0.00951 \\
\hline${ }^{230} \mathrm{U}$ & 0.00000215 \\
\hline${ }^{258} \mathrm{U}$ & 0.000000335 \\
\hline${ }^{208} \mathrm{Pu}$ & 17.5 \\
\hline${ }^{250} \mathrm{Pu}$ & 0.0616 \\
\hline${ }^{200} \mathrm{Pu}$ & 0.227 \\
\hline${ }^{2 * 1} \mathrm{Pu}$ & 112. \\
\hline 24s $\mathrm{Pu}$ & 0.00391 \\
\hline${ }^{211} \mathrm{Am}$ & 3.25 \\
\hline Heat source $\mathrm{Pu}$ & 14. \\
\hline Weapons grade $\mathrm{Pu}$ & $0.07^{a}$ \\
\hline
\end{tabular}

"Based on composition given in Table I with "+1Pu excluded because of negligible $\alpha$-activity contribution.

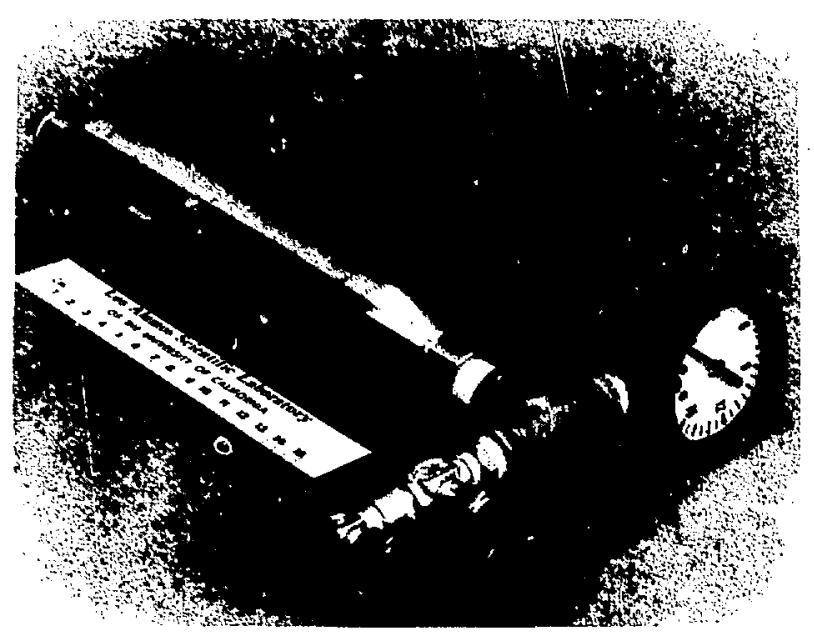

Fig. 2.

Laboratory experimental cylinder.

in exactly the same inanner, except that no radioactive contaminant was added. Gas samples were removed periodically and subjected to mass spectrographic analysis. Unless otherwise noted, cylinders were stored at $20^{\circ} \mathrm{C}$. After various periods of time up to 315 days, 22 of the cylinders were opened and their irradiated contents removed for examination and identification of degradation products.

Because temperatures in some storage facilities could reach $55^{\circ} \mathrm{C}$, thermal effects on radiolysis were also studied. Three cylinders containing $62 \mathrm{mg}$ ${ }^{200} \mathrm{Pu} / 52.5 \mathrm{~g}$ cellulosic waste were stored at $-13^{\circ} \mathrm{C}$, $20^{\circ} \mathrm{C}$, and $55^{\circ} \mathrm{C}$. The pressure in each was recorded daily, and the rates of pressure increase were compared.

To determine if increasing pressure would affect gas production rates (approach to equilibrium), one cylinder containing $62 \mathrm{mg}{ }^{200} \mathrm{Pu} / 52.5 \mathrm{-g}$ cellulosic waste was fitted with a 0 - to $689.5-\mathrm{kPa}$ (100-psi) gauge, and sampled only after the pressure had reached full scale. The gaseous contents of this cylinder were also examined for evidence of recombination of gases; water was found.

introngly contaminated $\left(4 \times 10^{5} \mathrm{nCi} / \mathrm{g}\right.$ waste) samples of vinyl Bakelite and polyvinyl chloride were placed in all-glass systems because of the possibility of $\mathrm{HCl}$ generation. It was undesirable to pressurize this apparatus; therefore, significant pressure buildup was avoided by using Orsat-type gas burets to collect the formed gases.

Because free liquids are not permitted in contaminated waste, radioactively contaminated oils are sorbed on vermiculite before disposal. Vacuum pump oil is a significant fraction of this type of li. quid waste. Thereivis, two $300-\mathrm{cm}^{3}$ stainless steel cylinders containing contaminated, sorbed, DuoSea 1 vacuum pump oil were prepared. The first contained $35 \mathrm{~g}$ of oil on $17.5 \mathrm{~g}$ of vermiculite. Before sorption, $62 \mathrm{mg}{ }^{238} \mathrm{Pu}$ as oxide was dispersed thoroughly in the oil. The second cylinder contained the same quantities of DuoSeal and vermiculite, and was contaminated with $31 \mathrm{mg}$ of ${ }^{20} \mathrm{Pu}$ as oxide. The cylinder containing the higher TRU loading began pressurizing $48 \mathrm{~h}$ after closure. The cylinder with half as nuch contamination began pressurization in $108 \mathrm{~h}$.

The presence of sorbed water in 'TRU solid waste was believed to affect the rate of gas production from alpha attack. If this were true, then cellulosics could be prime suspects because they absorb water so readily. Therefore, we prepared an experimental cylinder containing $52.5 \mathrm{~g}$ of cheesecloth and $52.5 \mathrm{~g}$ of water by soaking the cloth and then handwringing it to remove as much water as possible. The wet cellulosic was then contaminated with 62 $\mathrm{mg}$ of ${ }^{23 .} \mathrm{Pu}$ as chloride solution. Gas generation in 
this cylinder was significantly higher than a comparable cylinder of dry cellulosics.

Matrices of simulated waste typical of that generated at Mound Laboratory were prepared and contaminated with ${ }^{250} \mathrm{Pu}$ at three different levels (Table III). They were equilibrated in $300-\mathrm{cm}^{3}$ stainless steel cylinders at ambient laboratory temperature $\left(20^{\circ} \mathrm{C}\right)$ for more than 400 days with no readable pressure on 0 - to $105-\mathrm{kPa}$ gauges.

Two candidate prefilter materials, GORETEX with WEBRIL BACK@ and GORETEX HEAVY POLYESTER 9 were cut into $5-\mathrm{cm}^{2}$ pieces and containinated as follows: $1.30 \mathrm{~g}$ of the former with 647 $\mathrm{mg}{ }^{239} \mathrm{PuO}_{2}$, and $7.93 \mathrm{~g}$ of the latter with $592 \mathrm{mg}$ ${ }^{23} \mathrm{PuO}_{2}$. The contamination layers on the filter material appeared to be uniform, with 4 to $8 \mathrm{mg}$ of $\mathrm{PuO}_{2}$ per $\mathrm{cm}^{2}$ of material. This layer of contamination was just less than the thickness required to cause a significant pressure drop across filters fabricated from these materials.

While some of these experiments were in progress, various considerations suggested the likelihood of retrievable storage times of greater than $20 \mathrm{yr}$. Therefore, the experimental period was extended beyond the original 6 months, with selected cylinders still under test.

\section{B. Field Array}

1. Drums Containing "su. In the LASL plutonium production facility, several containers of ${ }^{23} \mathrm{Pu}$-contaminated solid wastes were available for field evaiuation. Their waste contents included drybox sweepings, cheesecloth, emery paper, $\mathrm{PuO}_{2}$ $\mathrm{ThO}_{2}$-Mo cermets in chunks and powder, male and female die parts containing pressed cermet disks, foil, steel wool, brass and stainless steel capsules of impure ${ }^{2 s s} \mathrm{Pu}$ oxide, paper, rags, and neoprene artifacts. To supplement the laboratory results with actual field data, an instrumented array of $115-\ell$ drums containing the ${ }^{298} \mathrm{Pu}$-contaminated wastes was set up. The individual wastes were "bagged out" in $0.3-\mathrm{mm}$ polyvinyl chloride (PVC) and placed inside standard $115-\ell$ mild steel drums. Twi of these drums were then stacked in a concrete srorage cysk (Fig. 3) and placed in a trench in the LASI. aste disposal area. Twenty casks constituted a cell, isolated from the balance of the trench by earthen barriers. The first trench had six cells, the second and third had five each, conforming to the real estate available. For convenience, drums to be studied were placed in the top positions in the casks and instrumented to provide data for (1) temperature inside and outside the drum and underneath the cask

TABLE İI

\section{CONTAMINATION LEVELS OF SIMULATED MOUND LABORATORY WASTE}

\begin{tabular}{|c|c|c|c|c|}
\hline \multirow[b]{2}{*}{ Matrices } & \multirow{2}{*}{$\begin{array}{c}\text { Wt } \% \text { of } \\
\text { Drum Contents }\end{array}$} & \multicolumn{3}{|c|}{ Contamination Levels ( $\mathrm{nCi} / \mathrm{g})^{a}$} \\
\hline & & Strong & Medium & Weak \\
\hline $\begin{array}{l}\text { Plastics } \\
45 \% \text { polyethylene } \\
45 \% \text { polypropylene } \\
10 \% \text { polyvinyl chloride }\end{array}$ & 19 & $15 \times 10^{8}$ & $7.5 \times 10^{8}$ & $2 \times 10^{8}$ \\
\hline $\begin{array}{l}\text { Gloves, drybox } \\
\text { Neoprene/Hypalon/Pb }\end{array}$ & 56 & $4 \times 10^{\circ}$ & $2 \times 10^{\circ}$ & $4 \times 10^{\circ}$ \\
\hline $\begin{array}{l}\text { Cellulosics } \\
\text { Rags } \\
\text { Paper }\end{array}$ & 25 & $2 \times 10^{\circ}$ & $1.5 \times 10^{8}$ & $1 \times 10^{\circ}$ \\
\hline
\end{tabular}




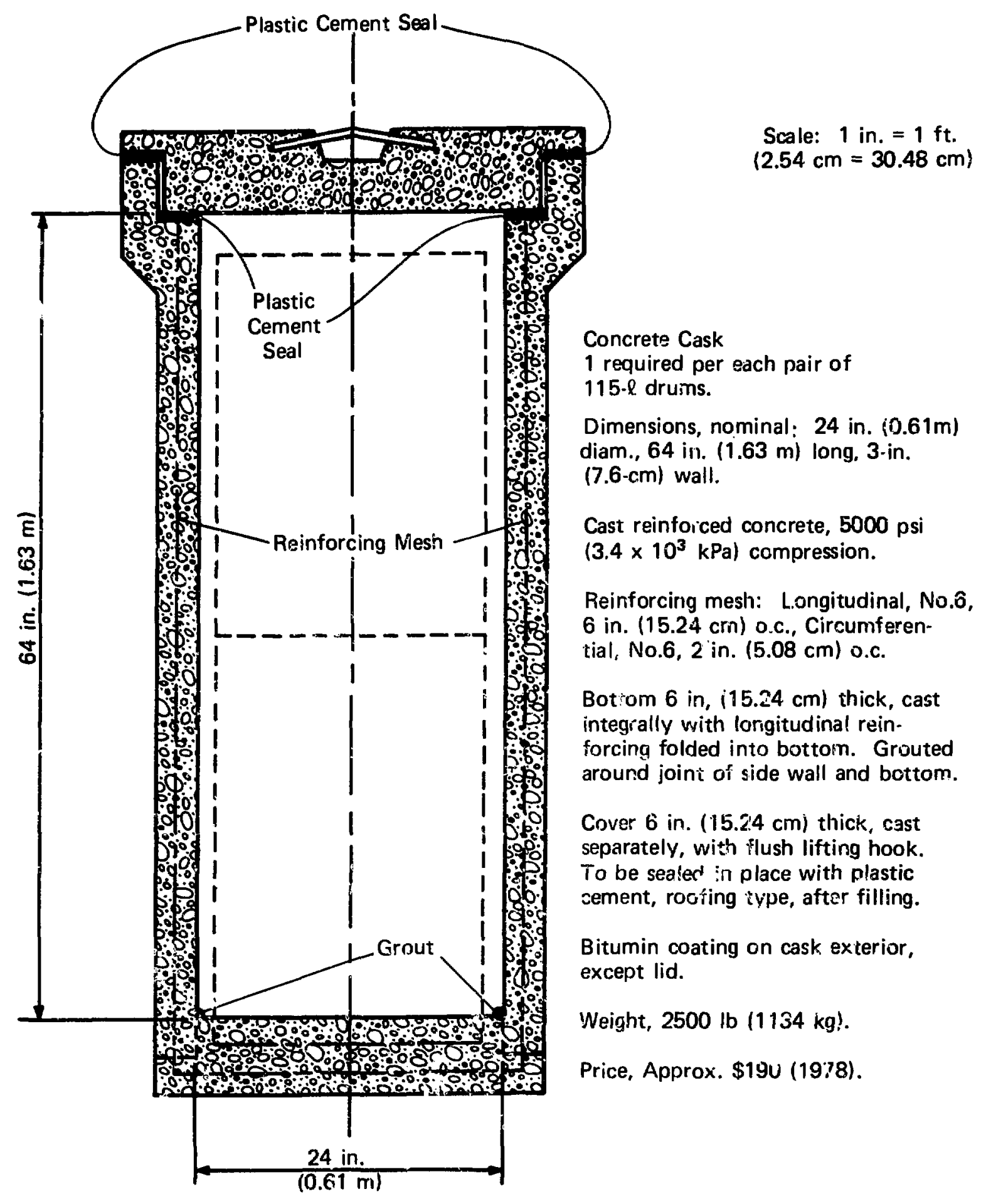

Fig. 3.

Section througin center of concrita cask. 
and (2) pressure inside and outside the cirum. In addition, gas samples can be withdrawn from the drums, the casks, or the head space outside the casks in each cell. Soil moisture beneath the cask can also be measured. Figure 4 shows the heads of some of the casks with the sampiing connections in place. The covers were sealed to the cusks with an asphaltic-type plastic cemient. The casks were then covered with galvanized, corrugated iron decking (Fig. 5) to allow air space. The iron decking was covered with $1 \mathrm{~m}$ of earth hackfill. After 94 days' storage, gas samples were withdrawn from the instrumented druins and casks and appropriate temperatures were recorded. Periodic monitoring of temperatures and gas compositions has continued.

2. Drums Containing ${ }^{23} \mathrm{Pu}$. Approximately $30 \mathrm{~S}$ mild steel $210 \cdot \ell$ drums filled with ${ }^{280} \mathrm{Pu}$ cont aminated solid wastes had also accumulated in the L.ASL waste disposal area. The oldest of these drums had been exposed to the elements for more than 2 yr. A representative group was selected, the gas contents sampled, and the drums were opened to ascertain the state of preservation of the containers and contents. An air-free sampling device was tesigned and fabricated. ${ }^{10}$ Each selected drum was sampled; gas was withdrawn for mass spectrographic analysis. The hole in the drum was resealed, the drum opened at the head, and the contents examined for evidence of radiolytic attack.

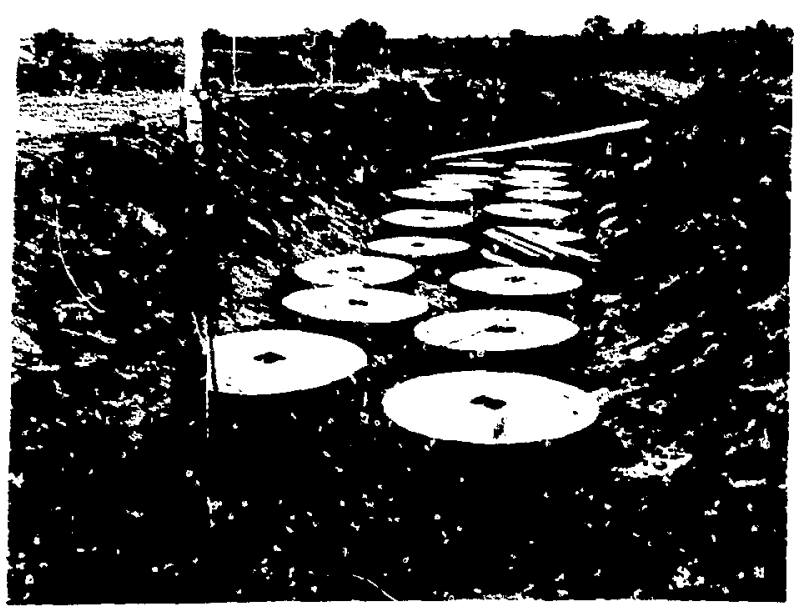

Fig. 4.

Casks with sampling consnections in place.

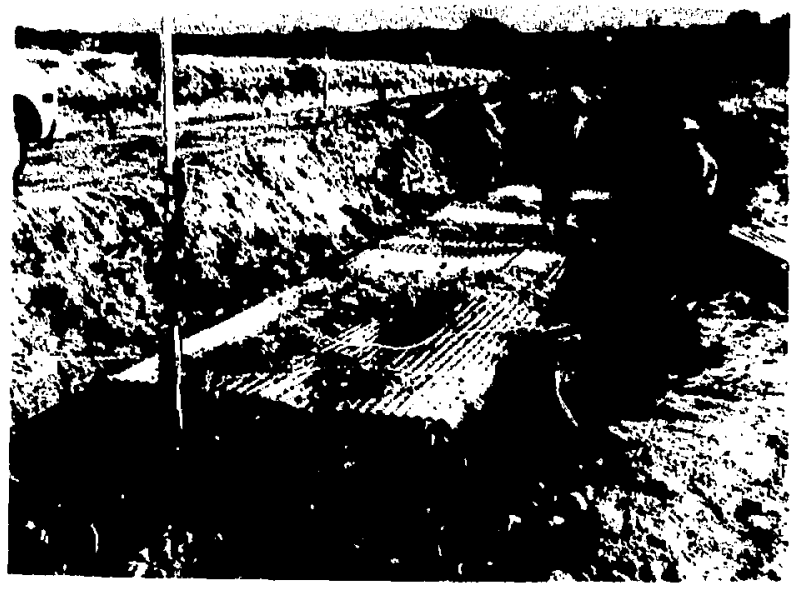

Fig. 5.

Corrugated iron decking in place over casks.

\section{Explosimeter Studies}

Thirteen $115-\ell$ drums of ${ }^{239} \mathrm{Pu}$-contaminated waste, contained in concrete casks in trench storage at the LASL waste storage area, were instrumented to monitor gas composition and pressure inside and outside the drums, and temperature in and around them, as well as under the casks. The distribution of TRU in the waste matrices is completely random and uncontrolled. The drums chosen to monitor were those with comparatively high $(\sim 20 \mathrm{~g}){ }^{230} \mathrm{Pu}$ content, generally present as the oxide. The waste matrices included "combustibles," plastics, paper, "trash," filters, rags, and plastic vials and bags, "sweepings," crucibles, scrap metal, and graphite powder. Feriodic sampling and analyses of the gas mixtures generated in these drums showed some of them to be potentially explosive. None of the drums pressurized above $1 \mathrm{~atm}$, due to diffusion of gases through the gasketed drum closures, the concrete casks, and the soil overburden. The escaping gases are not radioactive, so their diffusion to and dilution by the atmosphere is harmless. Actually, it is fortuitous because pressurization of the drums would be unacceptable. Radiolytic attack on the hydroge:ous contents of experimental cylinders and waste containers aiike have generated gas mixtures containing $\mathrm{H}_{2}, \mathrm{CO}, \mathrm{CO}_{2}$, and $\mathrm{CH}_{4}$, and occasionally, especially in the presence of temperatures above ambient $\left(20^{\circ} \mathrm{C}\right)$, hydrocarbons with molecular 
weights up to 60 . To determine the explosible limits of these radioactively generated gas mixttres, a laboratory explosimeter was developed (Fig. 6). It consists of a rubber-stoppered Florence flask fitted with a stopcock and two electrodes that allow a radio-frequency arc to pass through the contained gas mixture. A range of gas mixtures for testing was obtained by diluting the gaseous contents from the experimental cylinders with air and argon. Gas samples withdrawn from the waste drums in the field array were tested for explosibility without dilution.

\section{RESULTS}

\section{A. Laboratory Array}

As stated previously, the experimental array was set up using ${ }^{25 a} \mathrm{Pu}$ in an attempt to compress 20 -yr "retrievable storage time" into 6 months' experimen-

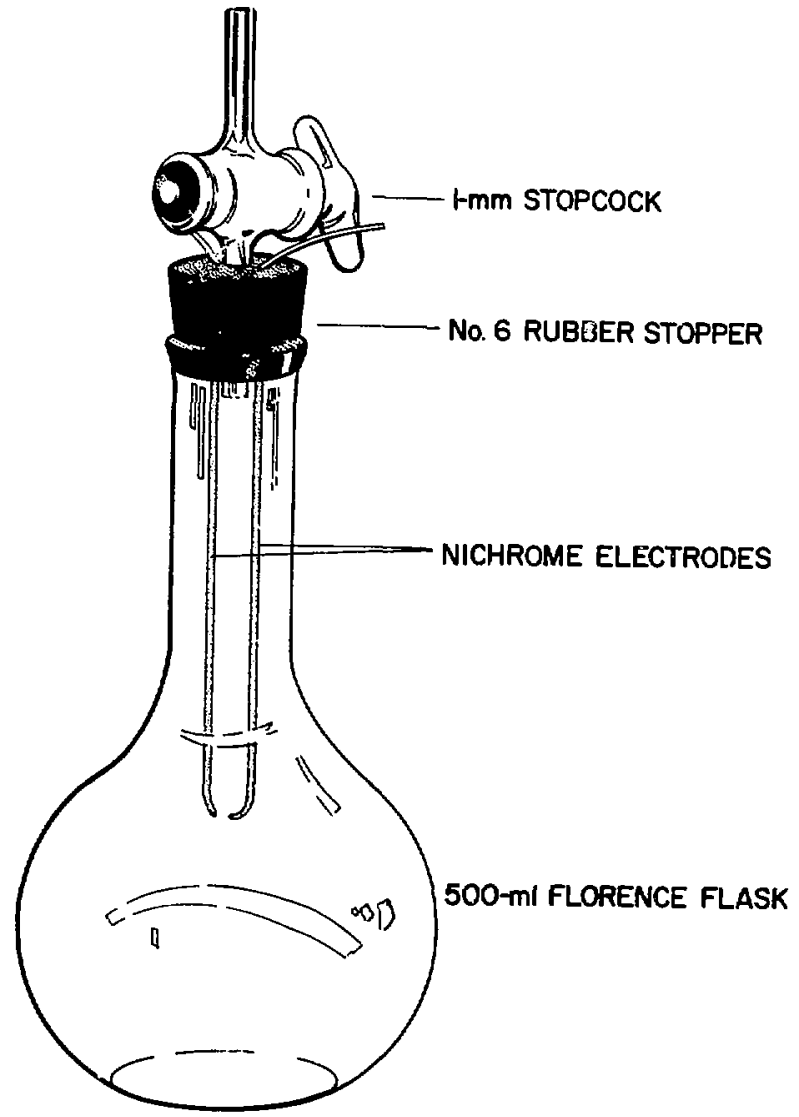

Fig. 6.

Explosimeter. tal time. Therefore, the actual quantities of ${ }^{\mathrm{N}} \mathrm{Pu}$ used were a factor of $\mathbf{4 0}$ higher than an equivalent energy dissipation from $200 \mathrm{~g}{ }^{20} \mathrm{Pu}$. The watt was selected as the fundamental energy term for the experiments and the associated calculations because it has the most universal application to the many scientific disciplines involved with radioactive waste management. Also it was assumed that the mean density of the hydrogenous waste used was 1.0. Therefore, the net volume of the experimental cylinders was taken to be $250 \mathrm{~cm}^{2}$. Observed pressures and the net volume were used to calculate the moles of evolved gas and the $G$ values. Each time the pressure in a cylinder reached 103.4 to $117.2 \mathrm{kPa}$ (15 to $17 \mathrm{psi}$ ) it was sampled, reducing the pressure to $6.9 \mathrm{kPa}$ (1 psi). Mass spectrographic analysis determined the composition of the withdrawn gas.

As the experiments proceeded, it became obvious that only the two higher contamination levels of ${ }^{238} \mathrm{Pu}$ on the polyethylene and cellulosics were evolving gas at any significant rate (Figs. 7 and 8 ). The other waste matrices in the array, even at the

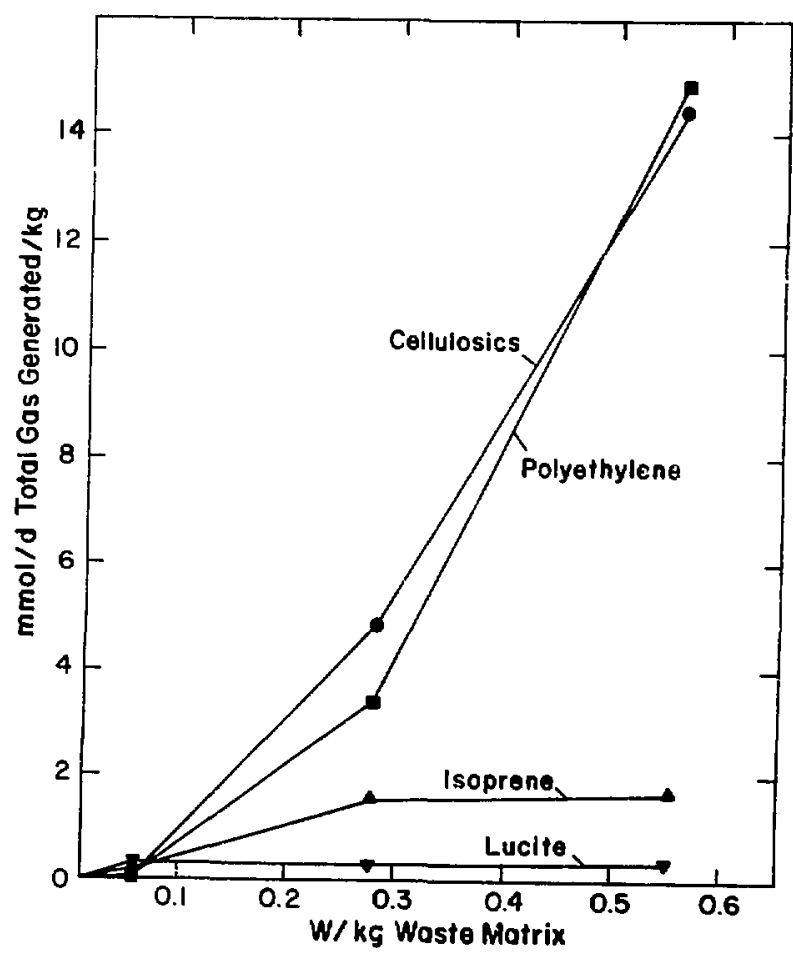

Fig. 7.

Gas generation in experimental waste matrices. 


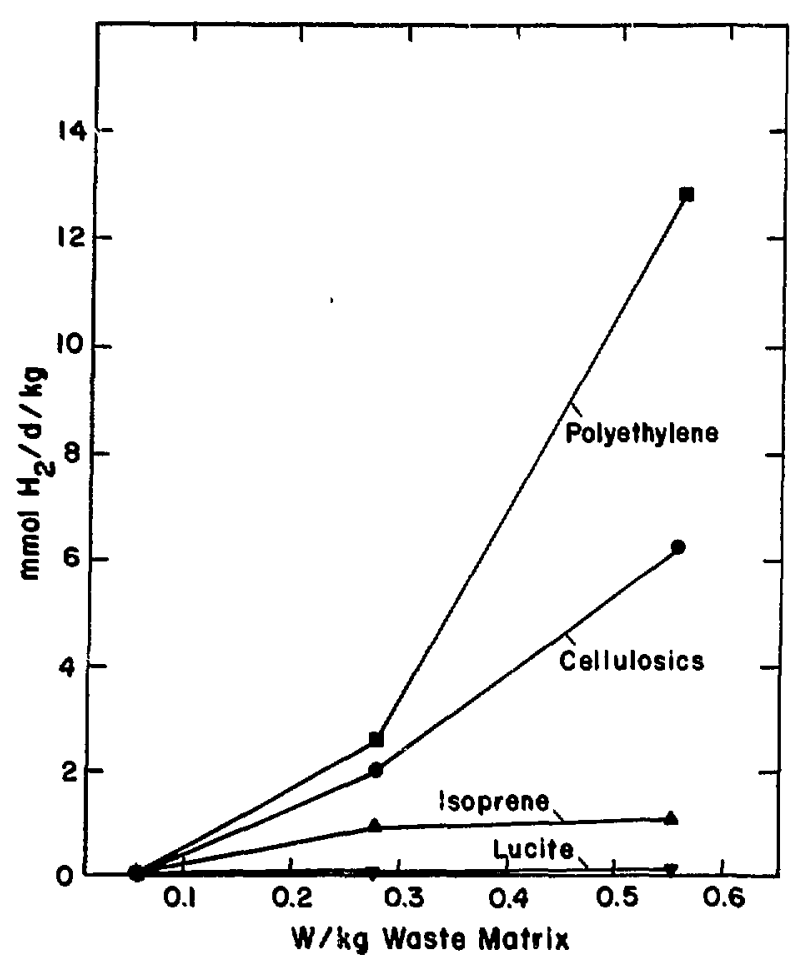

Fig. 8.

Hydrogen generation in experimental waste matrices.

highest contamination levels (with the possible exception of isoprene), showed no significant pressure increases for the initial 6 months' experiments (Fig. 9). Analyses of gas mixtures from experimental cylinders are shown in Figs. 10 through 15. Cylinder 1 (Fig. 10) contained dry cellulosics. Note that the major components of the gas mixture generated by this waste matrix are $\mathrm{H}_{2}$ and $\mathrm{CO}_{2}$. The quantities of the other combustible gases in the mixture, $\mathrm{CO}$ and $\mathrm{CH}_{4}$, are not significant. Cylinder 29 (Fig. 11) contained thin, low-density polyethylene bag material. The significant component of the gas mixture is $\mathrm{H}_{2}$. Cylinder 24 (Fig. 12) contained a mixture of cellulosics, plastics, and rubbers, representative of the average TRU-contaminated waste generated at LASL. Here again, the major components of the radiolytically generated gas mixture are $\mathrm{H}_{2}$ and $\mathrm{CO}_{2}$. The contents of Cylinder 35 (Fig. 13) were wet cellulosics, and again we see mainly $\mathrm{H}_{2}$ and $\mathrm{CO}_{2}$ generated by alpha attack of the matrix. Cylinders 33 and 34 (Figs. 14 and 15) contained DuoSea ${ }^{\circledR}$ vacuum pump oil sorbed on vermiculite. $H_{2}$ was the

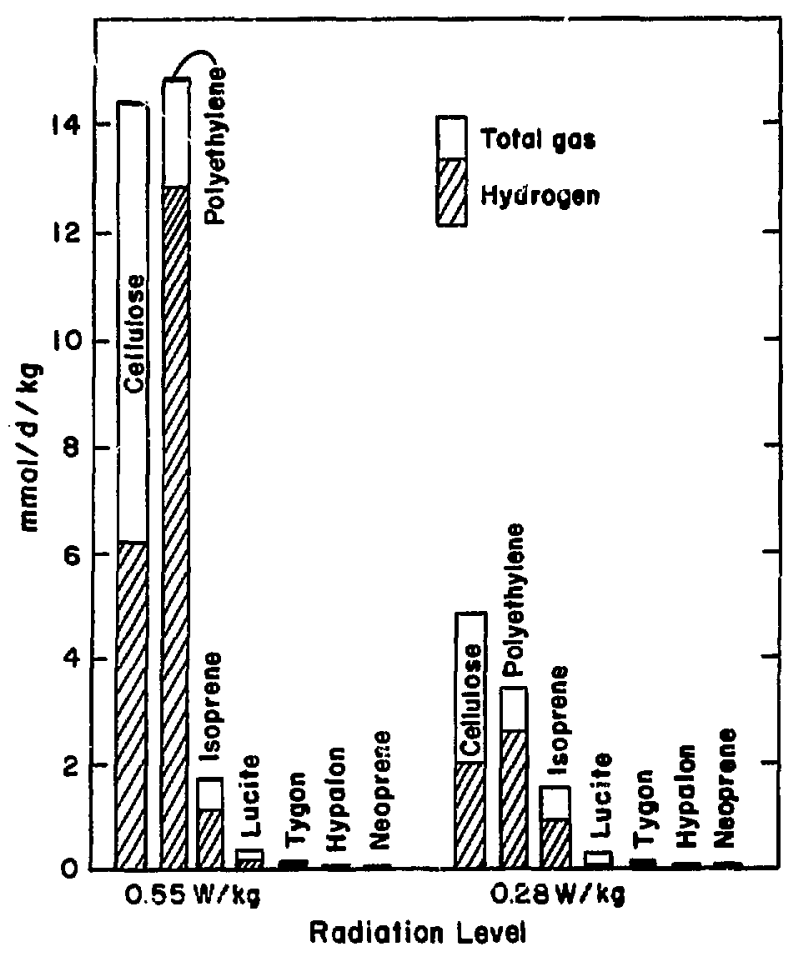

Fig. 9.

Comparison of gas generation from various waste matrices.

only gas present in significant quantity in the mixture, with $\mathrm{CH}_{4}$ a distant second. $\mathrm{CO}_{2}$ never exceeded $0.6 \%, \mathrm{CO} 0.7 \% . \mathrm{O}_{2}$ was not plotted on the graph because it was $<0.1 \%$ at the first sampling, and never exceeded that value. Atmospheric $\mathrm{N}_{2}$ was depleted by repeated dilution and virtually disappeared after the third sampling. In no case was $\mathrm{N}_{2}$ or $\mathrm{NO}_{x}$ generated, nor did it enter into any reactions in any of the cylinders.

After termination of the experiments, the cylinders were opened as noted above. A tan powder was found throughout all the cellulosics waste matrices. For those cylinders containing only cellulosics, approximately $10 \%$ of the original weight of the waste was powdered. For cylinders containing a mixture of waste, the weight of powder was proportionately less, indicating that it was mostly a degradation product of cellulosics. The powder contained approximately $50 \%$ of the TRU contaminant that was added originally. It was highly combustible, with an ash content of $<1 \%$. No other waste matrices showed similar degradation products except 


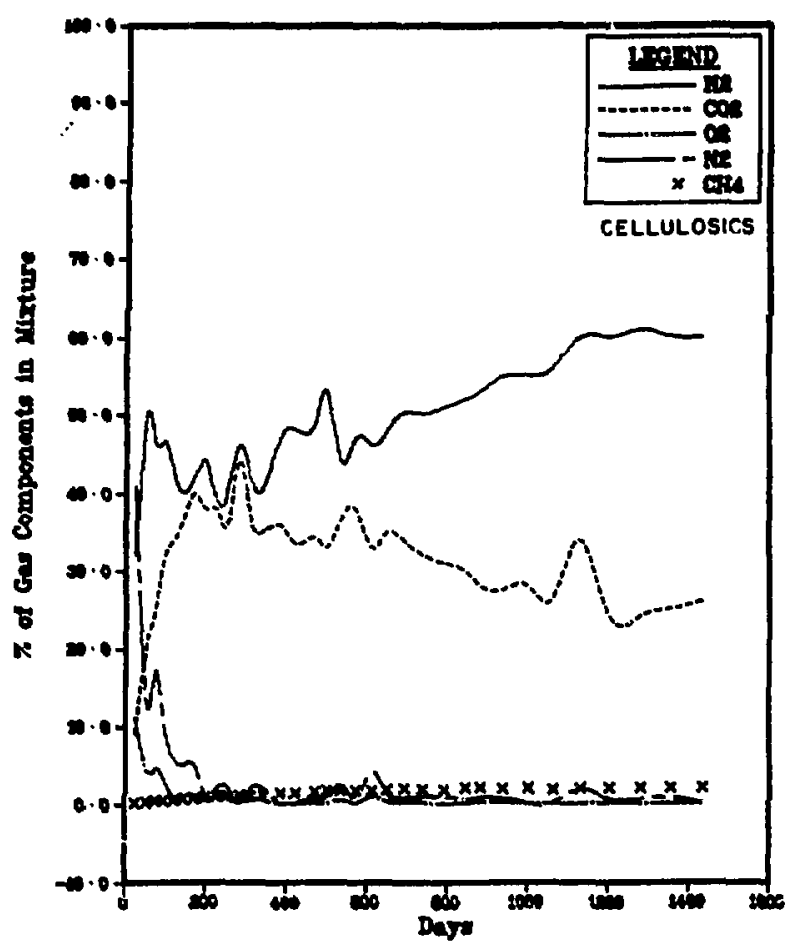

Fig. 10 ,

Gas mixture in Cylinder 1 .

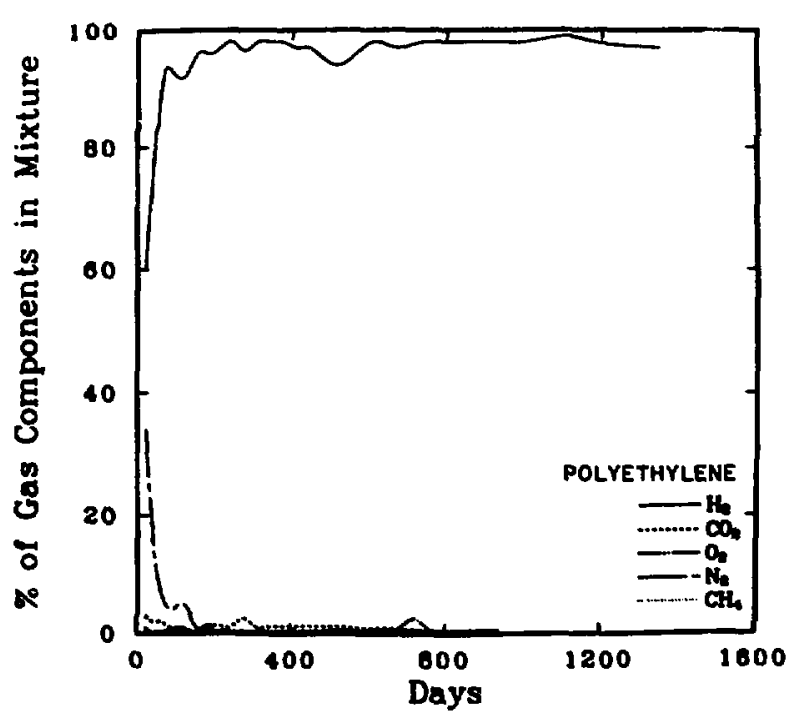

Fig. 11.

Gas mixture in Cylinder 29.

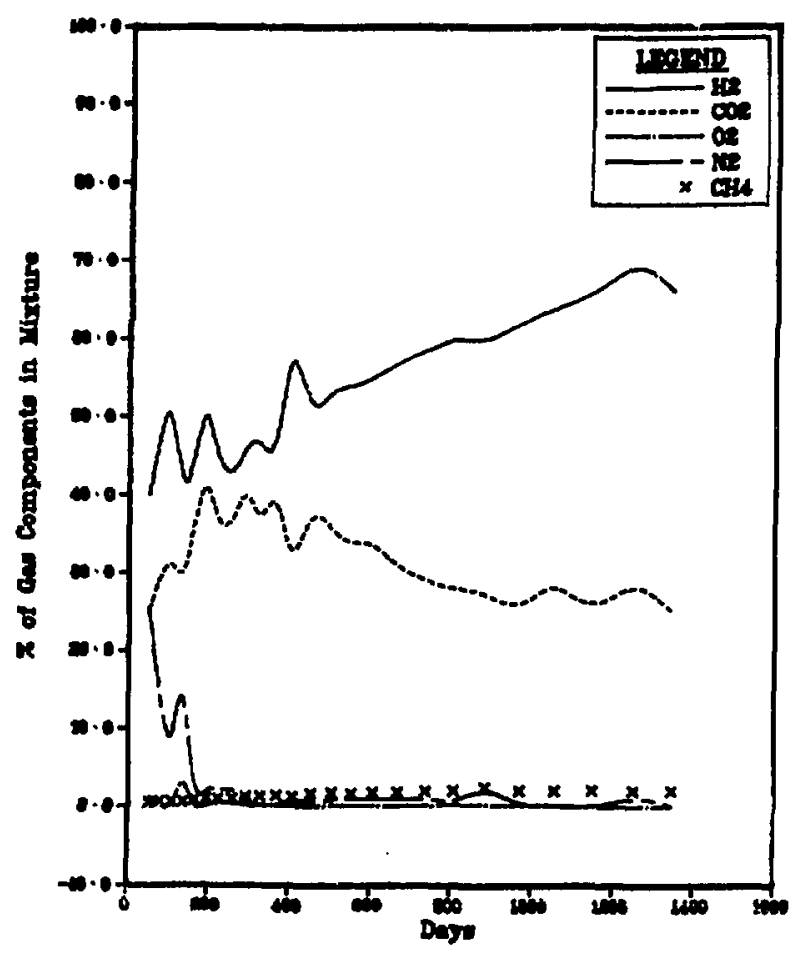

Fig. 12.

Cylinder 24. Cellulosics, plastics, and rubbers.

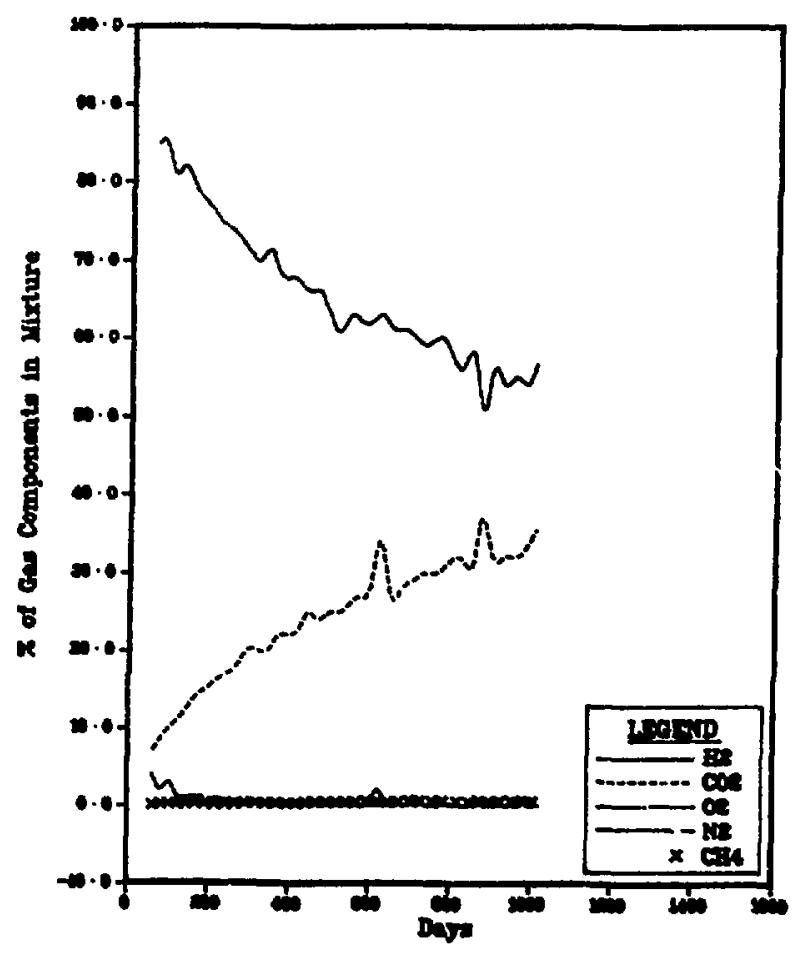

Fig. 13.

Wet cellulosics. 


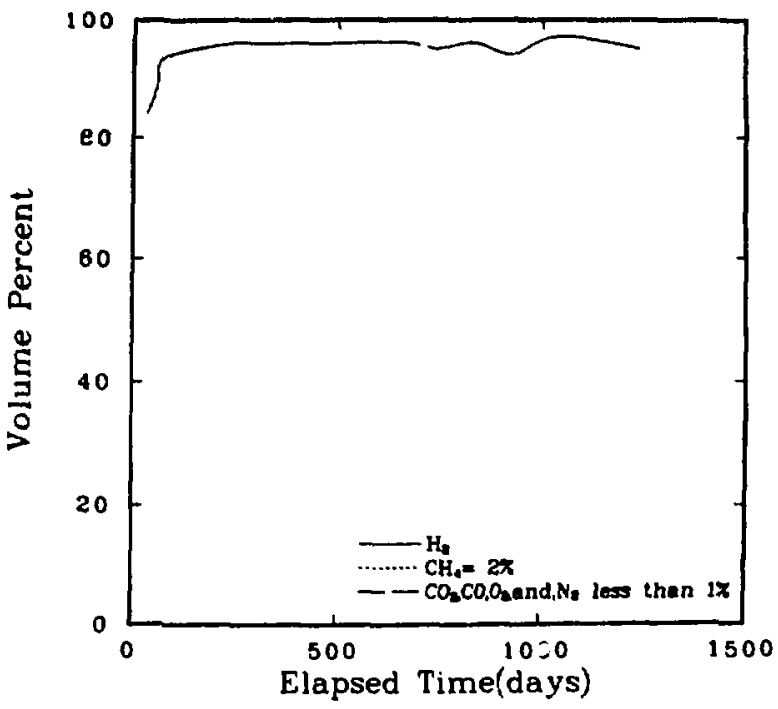

Fig. 14.

DuoSeal@on vermiculite.

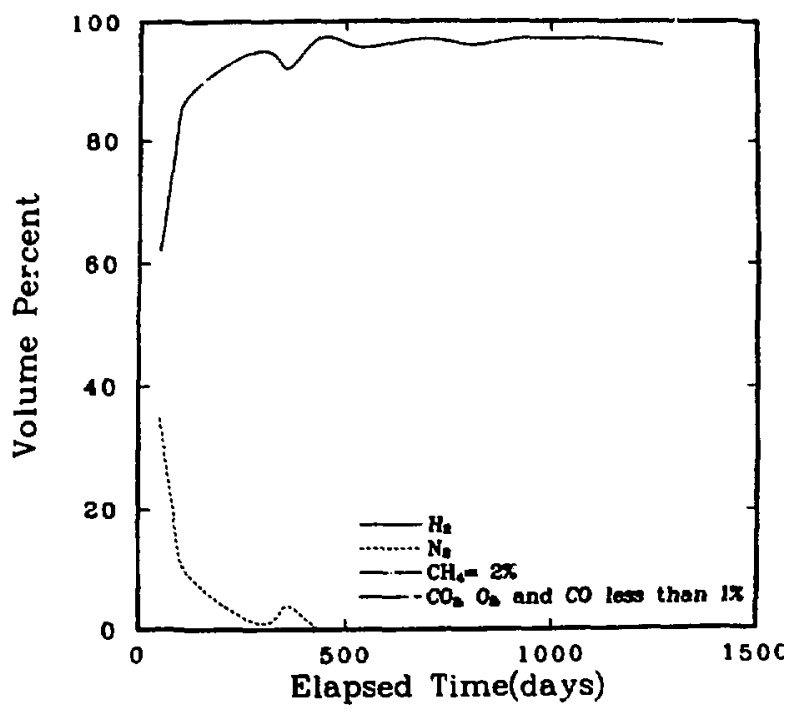

Fig. 15.

DuoSeal@on vermiculite.

stroigly contaminated neoprene drybox glove material. A rust-colored grarular material was separated from the original neoprene loading and found to leave a residue of $50 \mathrm{wt} \%$ ash after ignition at $1000^{\circ} \mathrm{C}$ for $30 \mathrm{~min}$.

Three of the experimental cylinders, each loaded with $52.5 \mathrm{~g}$ of cellulosics and contaminated with 62 $\mathrm{mg}$ of ${ }^{230} \mathrm{Pu}$, were stored at $-13^{\circ} \mathrm{C}, 20^{\circ} \mathrm{C}$ (room tem-

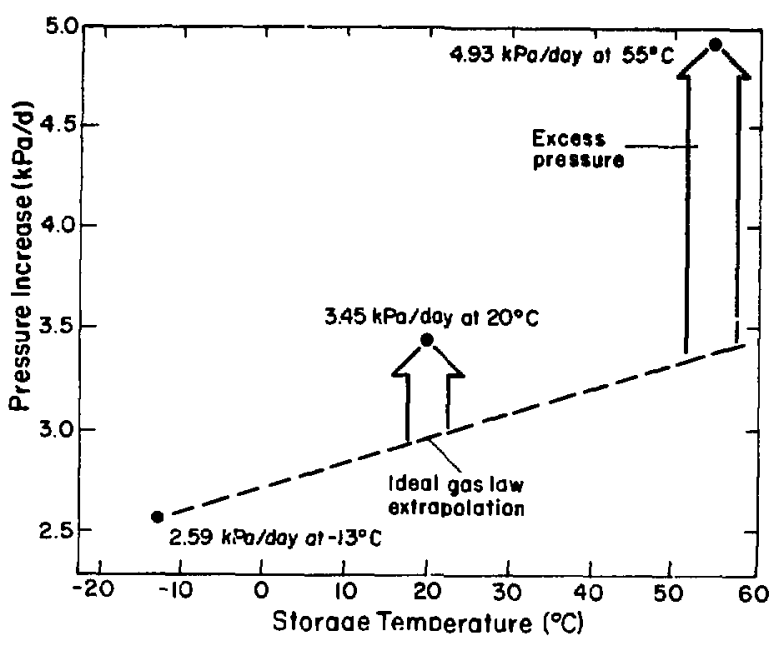

Fig. 16.

Enhancement of gas generation with increasing temperature.

perature), and $55^{\circ} \mathrm{C}$. Each continued to generate a gas mixlure of $\mathrm{H}_{2}, \mathrm{CO}, \mathrm{CO}_{2}$, and $\mathrm{CH}_{4}$. The composition of the mixture generally was independent of the storage temperature. However, the $55^{\circ} \mathrm{C}$ cylinder also generated a gas of about 60 molecular weight. The rates of pressure increase were significantly different, increasing with temperature at a rate greater than predicted by the ideal gas law. An analysis of variance performed on the data indicated that the pressure differences were highly significant and could not be attributed to experimental error, suggesting a synergistic enhancement of gas generation with increasing temperature. Figure 16 illustrates this enhancement. Figure 17 compares gas production rates for two cylinders containing cellulosics and identical quantities of ${ }^{238} \mathrm{Pu}$ contaminant. Both cylinders were held at ambient temperature $\left(20^{\circ} \mathrm{C}\right)$ for a year. Cylinder 1 was then cooled to $-13^{\circ} \mathrm{C}$ from day 370 to day 430 . During this same time, Cylinder 22 was heated at $55^{\circ} \mathrm{C}$. The effects of these temperature changes are apparent in the graph. The cylinders were returned to room temperature $\left(20^{\circ} \mathrm{C}\right)$, and then at day 540 , Cylinder 22 was put back into the oven, and has been held at $38^{\circ} \mathrm{C}$ since, whereas Cylinder 1 was continued at $20^{\circ} \mathrm{C}$. Note that the immediate effect on Cylinder 22 was increased rate of gas production, but with time the effect became less pronounced. In addition, the traces on the graph representing both cylinders 


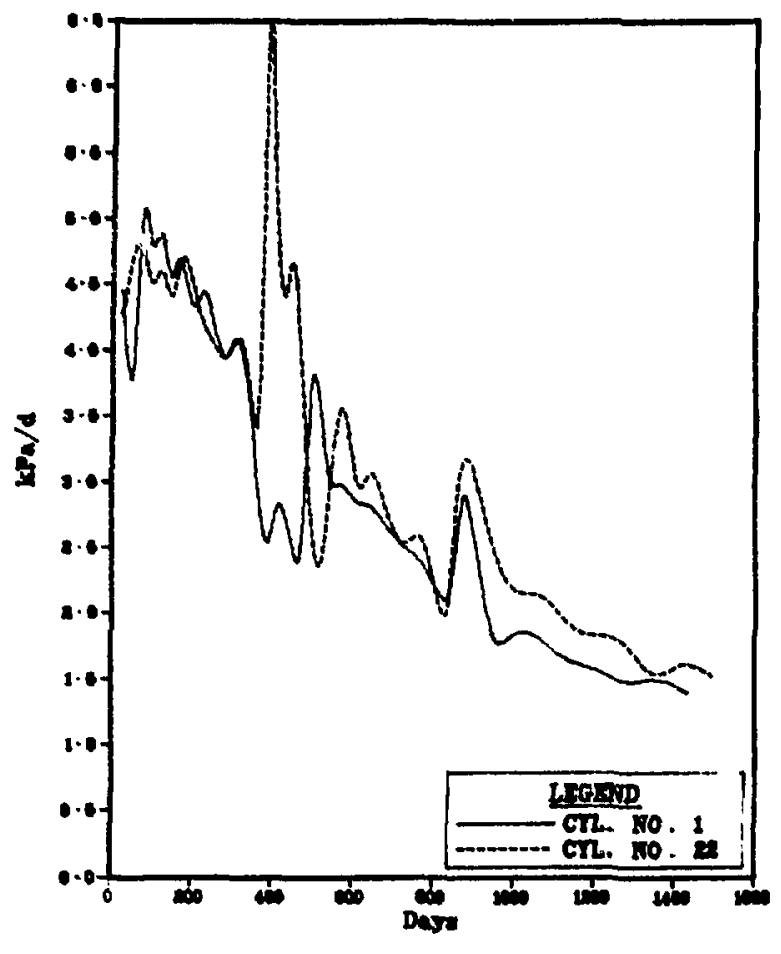

Fig. 17.

Temperature effects.

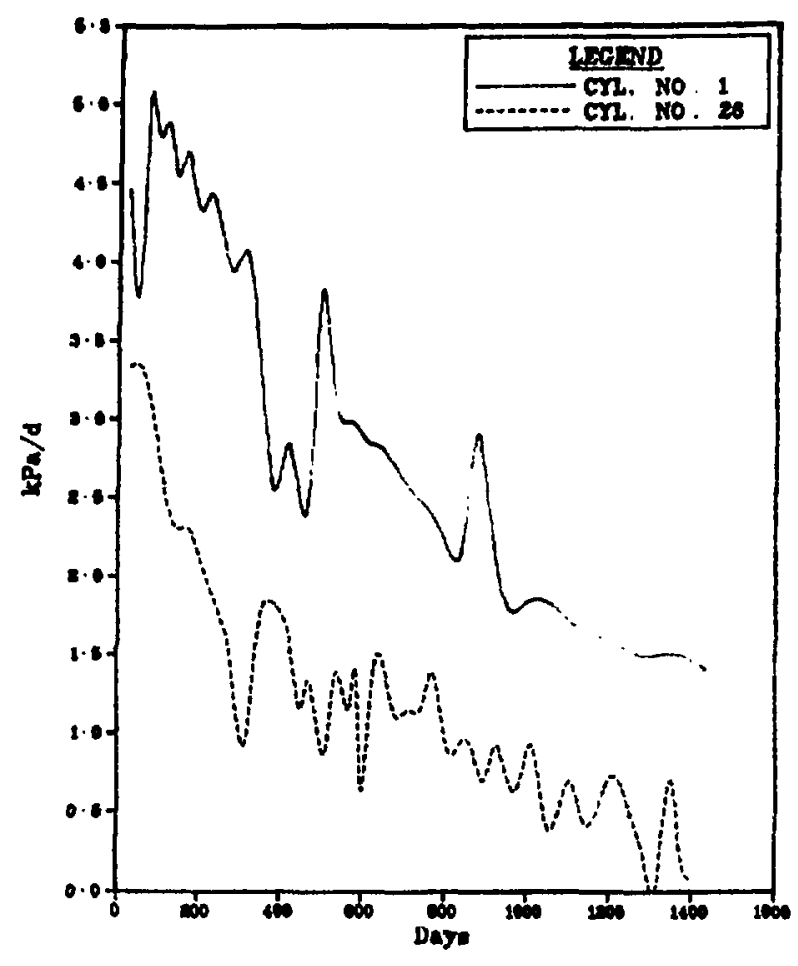

Fig. 18.

Comparison of rates of gas pressure build-up in two experimental cylinders.

rate of gas formation was less in the more highly pressurized cylinder. It also shows that in both cylinders there was a diminution in rate with time, a phenomenon previously discussed. The $g$ ises formed in Cylinder 26 were the same as those formed in other cylinders filled with contaminated cellulosics (Table IV). In addition, water was found in this gas mixture, but not in the gas mixture from Cylinder 1 , where the gas was withdrawn frequently. After the gas composition sample was withdrawn from Cylinder 26 at $\sim 3.9 \mathrm{yr}$, an additional series of samples was withdrawn over a 60-day period, gradually lowering the pressure in the cylinder from 669 to 48 $\mathrm{kPa}$. Water was determined repeatedly in these samples, and was being generated at the rate of 10.5 $\mu \mathrm{g} \mathrm{H}_{2} \mathrm{O} / \mathrm{g}$ cellulosic waste/yr.

The strongly contaminated vinyl Bakelite and polyvinyl chloride (PVC) samples were placed in all-glass apparatus because we suspected that $\mathrm{HCl}$ might be a degradation product. Vinyl Bakelite produced $100 \mathrm{~cm}^{2}$ of gas in 69 days. This gas was 
TABLE IV

\section{COMPOSITION OF GAS MIXTURE IN CYLINDER 26 (mol\%)}

\begin{tabular}{|c|c|c|c|c|}
\hline Component & $\begin{array}{c}285 \\
\text { Days }\end{array}$ & $\begin{array}{c}371 \\
\text { Days }\end{array}$ & $\begin{array}{c}508 \\
\text { Days }\end{array}$ & $\begin{array}{l}1426 \\
\text { Days }\end{array}$ \\
\hline $\mathrm{H}_{2}$ & 50 & 51 & 50 & 54 \\
\hline $\mathrm{CO}_{2}$ & 32 & 32 & 35 & 36 \\
\hline $\mathrm{CO}$ & 10 & 10 & 7 & 4 \\
\hline $\mathrm{CH}_{4}$ & 0.8 & 0.9 & 1.0 & 1.0 \\
\hline $\mathrm{O}_{2}$ & $<0.1$ & $<0.1$ & $<0.1$ & $<0.1$ \\
\hline $\mathrm{N}_{2}$ & 8 & 6 & 6 & 3 \\
\hline
\end{tabular}

analyzed mass spectrographically and found to contain $4 \% \mathrm{H}_{2}, 2 \% \mathrm{CO}, 0.9 \% \mathrm{CO}_{3}$, and $0.2 \% \mathrm{CH}_{4}$. The spectrograph did not detect $\mathrm{Cl}$ or $\mathrm{HCl}$, but wet chemical analysis found $0.06 \% \mathrm{Cl}$. At the time the gas sample was taken, the contaminated matrix was still intact, pliable, and only slightly darkened in color. Kazanjian and Horrell ${ }^{11}$ estimated that PVC would withstand indefinite alpha attack from lowlevel waste at ambient temperature. However, they found a strong synergism between thermal and radiative effects when the temperature was $60^{\circ} \mathrm{C}$ and the radiation several orders of magnitude greater than that found in ordinary TRU waste. Attack by heat produces up to $50 \mathrm{wt} \%$ chlorine from chlorinated vinyls; therefore, we assumed that radiolytic decomposition would be comparable. $\mathrm{Ob}$ viously this was not the case. In an additional 280 days, these materials continued to darken and were somewhat embrittled, but still intact, and the vinyl Bakelite had produced only an additional $10 \mathrm{~cm}^{3}$ of gas. The PVC bagout material showed resistance to radiolytic attack similar to that shown by the vinyl Bakelite. In 335 days it produced only $10 \mathrm{~cm}^{3}$ of gas mixture, containing $0.6 \% \mathrm{H}_{2}, 0.1 \% \mathrm{CO}, 1.0 \% \mathrm{CO}_{2}$, and $0.1 \% \mathrm{CH}_{4}$. The balance of the sample was oxygen-depleted air.

Cylinder 36 contains $52.5 \mathrm{~g}$ of $100 \%$ cross-linked high-density polethylene cut into pieces $\sim 1$ by $5 \mathrm{~cm}$ and contaminated with $62 \mathrm{mg}{ }^{238} \mathrm{Pu}$. The contaminant was placed on the plastic as was the chloride solution, and dried in place before loading. The cylinder was fitted with the usual 103.4-kPa (15-psi) pressure gauge and has been closed for $>1300$ days
TABLE V

\section{GAS MIXTURE FROM RADIOLYTIC ATTACK OF HIGH-DENSITY POLYETHYLENE}

\begin{tabular}{|c|c|c|c|c|c|c|}
\hline \multirow{2}{*}{$\begin{array}{l}\text { Days } \\
\text { Elapsed }\end{array}$} & \multicolumn{6}{|c|}{ Gas Composition (mol\%) } \\
\hline & $\mathbf{H}_{\mathbf{2}}$ & CH. & $\mathbf{O}_{2}$ & $\mathrm{CO}$ & $\mathrm{CO}_{2}$ & $\underline{\mathbf{N}_{2}}$ \\
\hline 674 & 5.0 & 0.1 & $<0.1$ & $<0.1$ & 17 & 77 \\
\hline 1318 & 4.0 & $<0.1$ & $<0.1$ & 0.4 & 20 & 75 \\
\hline
\end{tabular}

without pressurizing. At day 674 , and again at day 1318, gas samples were withdrawn. Table V shows the resilts.

Matrices typical of Mound Laboratory wastes contaminated with ${ }^{238} \mathrm{Pu}$ at three different levels (Table III) were equilibrated in $300-\mathrm{cm}^{3}$, stainless steel cylinders (Fig. 2) at ambient laboratory temperature $\left(20^{\circ} \mathrm{C}\right)$ for more than 400 days without pressure increase. Mass spectrographic analysis of a was sample from the cylinder containing the must highly contaminated matrix showed the following composition: $\mathrm{H}_{2}, 0.6 \%$; $\mathrm{CH}_{4},<0.1 \% ; \mathrm{O}_{2}, 14.8 \%$; $\mathrm{CO}_{2}, 3.9 \%$; $\mathrm{CO}, 0.8 \%$; and $\mathrm{N}_{2}, 79.1 \%$. Examination of the cylinder's contents showed that the rags and paper had deteriorated the most, and neoprene the least. Figure 19 shows the waste matrices after removal from the test cylinder. If such wastes were to be reprocessed, they would require very careful handling because the disintegrated cellulosics contained the typical brown powder previously described: very low density, easily airborne, and highly contaminated.

\section{B. Field Array}

1. Drums Containing ${ }^{299} \mathrm{Pu}$. Table VI gives details of 20 drums selected for analysis and examination. Little evidence for gas generation from radiolytic attack was seen, and no pressurization was detected. It is virtually impossible to maintain a gas-tight seal on a typical waste storage drum. Therefore, any gases formed during the $\sim 2$-yr storage could easily have diffused to the atmosphere, and air probably diffused into the drums. Drum 128 appeared to have been better sealed than the others in the test group, and to have generated 


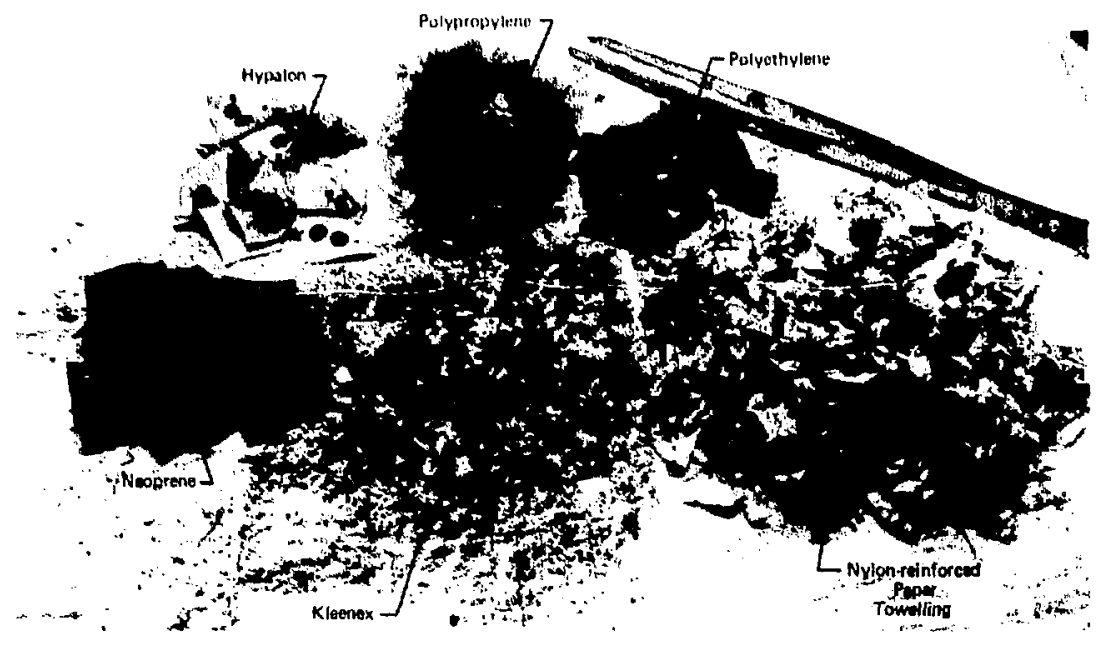

Fig. 19.

Degraded wastes removed from test cylinder.

enough gases to contain a potentially explosible mixture, but it was not pressurized above $1 \mathrm{~atm}$. The drum contained empty $2-\ell$ glass bottles that had held plutonium recovery solutions. Apparently they were not well rinsed before being discarded.

To see what the cumulative effect of a quantity of ${ }^{239} \mathrm{Pu}$-contaminated waste-filled containers might be, a closed. underground storage cell containing

2 - $57-\ell$ drums,

$304 \cdot 115-\ell$ drums,

$197 \cdot 210-\ell$ drums, and

52 - fiber glass reinforced plastic covered plywood boxes, of assorted sizes,

had gas samples withdrawn after remaining undisturbed for more than a year. This underground cell is approximately $15 \mathrm{~m}$ long, $8 \mathrm{~m}$ wide, and $8 \mathrm{~m}$ deep. The total volume of the waste is $407.5 \mathrm{~m}^{3}$. The atmosphere in the cell was sampled at one end near the top, and at the opposite end near the bottom. The results of the mass spectrographic analysis of the cell atmosphere are shown in Table VII.

2. Drums Containing ${ }^{23} \mathrm{Pu}$. Thirteen $115-\ell$ drums stored in covered trenches at the LASL waste burial site were chosen for instrumentation and monitoring. These drums, filled with ${ }^{2 s 8} \mathrm{Pu}$ contaminated waste, continue to generate gases, and presumably are representative of all drums in that storage. There is no way to measure the quan- tity of gas produced because it continually diffuses to the atmosphere through drum gaskets, cask walls, and earthen overburden. It is not contaminated. However, as shown in Table VIII, changes in the composition of the gas mixtures have taken place between samplings. This may be due partly to seasonal thermal cycling. It undoubtedly is enhanced by the periodic removal of gas samples. Each sampling removes 1 to $2 \%$ of the gaseous contents of the drum, and we must assume there is inward diffusion of air to bring the pressure in the drum back to $1 \mathrm{~atm}$. This would account for the persistence of oxygen in some of the mixtures in spite of the continuing production of $\mathrm{CO}$ and $\mathrm{CO}_{2}$. Drum 232 , at day 245 , appeared to contain an explosive mixture. It was sampled and tested in the explosimeter with negative results. Note that the $\mathrm{H}_{2}$ percentage decreased with age, whereas the $\mathrm{O}_{2}$ and $\mathrm{N}_{2}$ increased, indicating an influx of air. Drum 301 was sampled at day 36 , and the gaseous mixture was explosive. As it has grown older, the $\mathrm{H}_{2}$ and $\mathrm{CO}_{2}$ percentages in the mixtures have increased steadily; the $\mathrm{O}_{2}$ had dropped to $<0.1 \%$. Clearly, the contaminant is dispersed much more effectively in some drums than in others. The gaseous contents of Drum 330 reached an explosible state in 200 days. Note the decrease in $\mathrm{H}_{2}$ and the increase in $\mathrm{O}_{2}$ and $\mathrm{N}_{2}$ that followed. Again, apparently caused by an inward diffusion of air. 
TABLE VI

115- and 210- $\ell$ DRUMS OF ${ }^{20}$ Pu-CONTAMINATED WASTE SELECTED FROM STORAGE FOR ANALYSIS AND EXAMINATION

\begin{tabular}{|c|c|c|}
\hline $\begin{array}{l}\text { Drum } \\
\text { No. }\end{array}$ & $\begin{array}{c}\text { Months in } \\
\text { Storage }\end{array}$ & Description of Contents \\
\hline $1 \mathbf{A}$ & 28 & Leached plant process solids \\
\hline 2B & 28 & Leached plant prucess solids \\
\hline 12 & 15 & NUMEC and Haniord plant process solids \\
\hline 42 & 11 & Plastic trash \\
\hline 43 & 12 & Plastic and rubber packaging material \\
\hline 49 & 9 & Offsite processing solids and junk \\
\hline 66 & 9 & Hanford and plant processing solids \\
\hline 94 & 6 & Glass residue from process area \\
\hline 95 & 7 & Cellulose residue \\
\hline 126 & 7 & Sorted wastes (glass) \\
\hline 128 & 6 & Sorted wastes (glass) \\
\hline 141 & 5 & Sorted wastes (rubber) \\
\hline 149 & 6 & Sorted wastes (cellulosics) \\
\hline 151 & 5 & Hanford processing solids \\
\hline 161 & 6 & Sorted process-generated solids \\
\hline 163 & 6 & Sorted process-generated solids \\
\hline 194 & 7 & Hanford processing solids \\
\hline 201 & 6 & Hanford processing solids \\
\hline 248 & 2 & Hanford processing solids \\
\hline 270 & 2 & Hanford processing solids \\
\hline
\end{tabular}

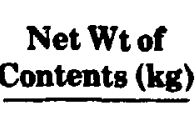

$\begin{array}{rrr}30.1 & 113 & 2.6 \times 10^{3} \\ 30.0 & 113 & 2.6 \times 10^{3} \\ 28.6 & 28.6 & 2.3 \times 10^{4} \\ 28.1 & 7.0 & 1.8 \times 10^{4} \\ 18.6 & 5.0 & 1.9 \times 10^{4} \\ & & \\ 33.6 & 16.2 & 3.4 \times 10^{\circ} \\ 32.7 & 13.5 & 2.9 \times 10^{\circ} \\ 39.1 & 1.6 & 2.9 \times 10^{3} \\ 9.5 & 3.2 & 2.4 \times 10^{4} \\ 28.6 & 7.5 & 1.8 \times 10^{4} \\ & & \\ 25.7 & 1.3 & 3.5 \times 10^{3} \\ 38.3 & 2.6 & 4.7 \times 10^{3} \\ 11.2 & 0.5 & 3.1 \times 10^{3} \\ 29.2 & 35.5 & 8.6 \times 10^{4} \\ 11.3 & 0.7 & 4.3 \times 10^{3} \\ & & \\ 43.1 & 2.5 & 4.1 \times 10^{3} \\ 12.4 & 42.5 & 2.4 \times 10^{3} \\ 68.8 & 149.6 & 1.5 \times 10^{\circ} \\ 46.8 & 101.4 & 1.5 \times 10^{3} \\ 28.7 & 72.8 & 1.8 \times 10^{3}\end{array}$

Gases Present (mol\%)

$\underline{\mathrm{H}}_{2} \quad \mathrm{CH}_{4} \quad \mathrm{O}_{2} \quad \mathrm{Ar} \quad \mathrm{CO}_{2} \quad \mathrm{CO}^{\mathrm{N}}$

$\begin{array}{ll}0 & 0 \\ 0 & 0.9 \\ 0.1 & 0 \\ 0 & 0 \\ 0.1 & 0 \\ & \\ 0 & 0 \\ 0 & 0 \\ 0 & 0 \\ 0 & 0 \\ 0 & 0\end{array}$

$\begin{array}{lllll}23 & 1 & 0.2 & 0.5 & 72 \\ 20 & 1 & 0.3 & 0.2 & 78 \\ 19 & 1 & 0.6 & 0.4 & 67 \\ 22 & 1 & 0.1 & 0.4 & 79 \\ 21 & 1 & 0.2 & 0.5 & 70\end{array}$

$\begin{array}{lllll}22 & 1 & 0.1 & 0.5 & 79\end{array}$

$\begin{array}{lllll}23 & 1 & 0.4 & 0.5 & 74\end{array}$

$\begin{array}{lllll}22 & 1 & 0.1 & 0.3 & 78\end{array}$

$\begin{array}{lllll}23 & 1 & 0.2 & 0.7 & 73\end{array}$

$\begin{array}{lllll}23 & 1 & 0.2 & 0.7 & 73 \\ 19 & 1 & 0.1 & 0.4 & 78\end{array}$

$\begin{array}{lllllll}18 & 0.2 & 13 & 0.7 & 16 & 5 & 48\end{array}$

$\begin{array}{lllllll}0 & 0 & 19 & 1 & 0.1 & 0.4 & 78\end{array}$

$\begin{array}{lllllll}0 & 0 & 20 & 1 & 0.4 & 0.5 & 68\end{array}$

$\begin{array}{lllllll}0 & 0 & 20 & 1 & 0.4 & 0.4 & 77\end{array}$

$\begin{array}{lllllll}0 & 0 & 20 & 1 & 0.1 & 0.4 & 79 \\ 0 & 0 & 20 & 1 & 0.3 & 0.4 & 70 \\ 0 & 0 & 20 & 1 & 0.7 & 0.4 & 79 \\ 0.1 & 0 & 18 & 1 & 3 & 0.3 & 68\end{array}$


TABLE VII

\section{ATMOSPHERE FOUND IN CLOSED INTERIM STORAGE CELL GAS COMPONENT (mol\%)}

\begin{tabular}{|c|c|c|c|c|c|}
\hline & $\mathbf{H}_{\mathbf{2}}$ & $\mathrm{CH}_{\mathbf{2}}$ & $\mathbf{O}_{2}$ & $\mathrm{CO}$ & $\mathrm{CO}_{2}$ \\
\hline Top & $<0.1$ & $<0.1$ & 21 & 0.2 & 0.4 \\
\hline Bottom & $<0.1$ & $<0.1$ & 20 & 0.1 & 0.5 \\
\hline
\end{tabular}

3. Explosimeter Studies. The explosimeter data obtained for the above drums showed the need to establish some parameters for predicting explosiveness. The variety of gas mixtures needed for this study was not available in the field array; therefore, the mixtures were synthesized from the gaseous contents of the laboratory experimental cylinders, air, and argon. Hydrogen commonly is accepted to be explosible in air when present in the 4to $76-\mathrm{vol} \%$ range. We suspected that the typical gas mixture found in contaminated waste containers $\left(\mathrm{H}_{2}, \mathrm{CO}, \mathrm{CO}_{2}, \mathrm{CH}_{4}\right.$, residual air, and possible traces of hydrocarbons) might have different explosible limits. In an attempt to establish these limits, more than 80 explosimeter tests were performed. The results are shown in Table IX.

\section{DISCUSSION}

In addition to the work reported here, Kazanjian" and Bibler ${ }^{2}$ have studied gas production by radiolytic attack of hydrogenous waste and have found similar mixtures of gases, hydrogen being the predominant gas produced. Because the conditions of the experiments varied, it is difficult to compare results. Kazanjian states that "appreciable amounts of hydrogen are usually produced, but will not be accompanied by oxygen in a drum for most of the storage period." This is in agreement with our findings, but does not take into acriount the probability of air diffusion into the drums.

The volume of gases generated by the alpha radiolytic attack of hydrogenous materials is dependent on the quantity of radionuclide present, the size and distribution of the particles of TRU material, and the identity of the hydrogenous substrate. To avoid the possibility of achieving criticality in waste storage, ${ }^{20} \mathrm{Pu}$ is limited to $200 \mathrm{~g}$ of weapons-grade material per $210-\ell$ drum. This is a contamination equivalent to $4 \times 10^{3} \mathrm{nCi} / \mathrm{g}$ waste. In actual practice, this level of contamination seldom is achieved. Studies of several years' records for contaminated waste stored at LASL and also at INEL indicate that very few drums contain anywhere near the limit. The average is $<10 \mathrm{~g}$ of ${ }^{23} \mathrm{Pu}$ per $210-\ell$ drum, and many drums contain $1 \mathrm{~g}$ or less. Such drums do not generate measurable quantities of gas.

Elevated temperature was found to increase the rate of gas formation (Fig. 17) and additional work in progress corroborates this finding. However, careful study of Fig. 17 reveals that this effect appears to diminish with time. For a long-term isolation, I believe it will cease to be significant. Extrapolation of the curve shown in Fig. 20 reinforces this belief. Please recall the temperature history of Cylinder 22: 1 yr at $20^{\circ} \mathrm{C}, 0.25$ yr at $55,0.23$ yr at 20 , and $3.5 \mathrm{yr}$ at 38 (to present).

The rate of gas formation decreases as pressure increases (as observed in Fig. 18); the possible benefit in case of deep underground disposal is obvious. If, as the data seem to indicate, this phenomenon is the result of recombining $\mathrm{H}_{2}$ and $\mathrm{O}_{2}$, then the rate of water formation probably would be greater initially than the $10.5 \mathrm{mg}$ of $\mathrm{H}_{3} \mathrm{O} / \mathrm{kg}$ of cellulosic waste/yr observed. However, it would diminish as $\mathrm{H}_{2}$ production diminished (Fig. 21) and a source of $\mathrm{O}_{2}$ was no longer available. Extrapolation of this curve shows that the diminution of water production probably would take place during the working life of a repository; for the long term, the gas and water production would be insignificant. Molecke has affirmed ${ }^{12}$ that shallow land burial or underground storage does not create a problem-but at the rate of gas generation shown, radiolytically generated gas formation in a sealed deep geologic disposal appears not to be a problem, either. The author believes that the ongoing LASL research and development radiolysis studies for the Waste Isolation Pilot Plant (WIPP) will corroborate this statement. 
TABLE VIII

DATA FROM ${ }^{29}$ Pu-CONTAMINATED WASTE IN COVERED-TRENCH STORAGE

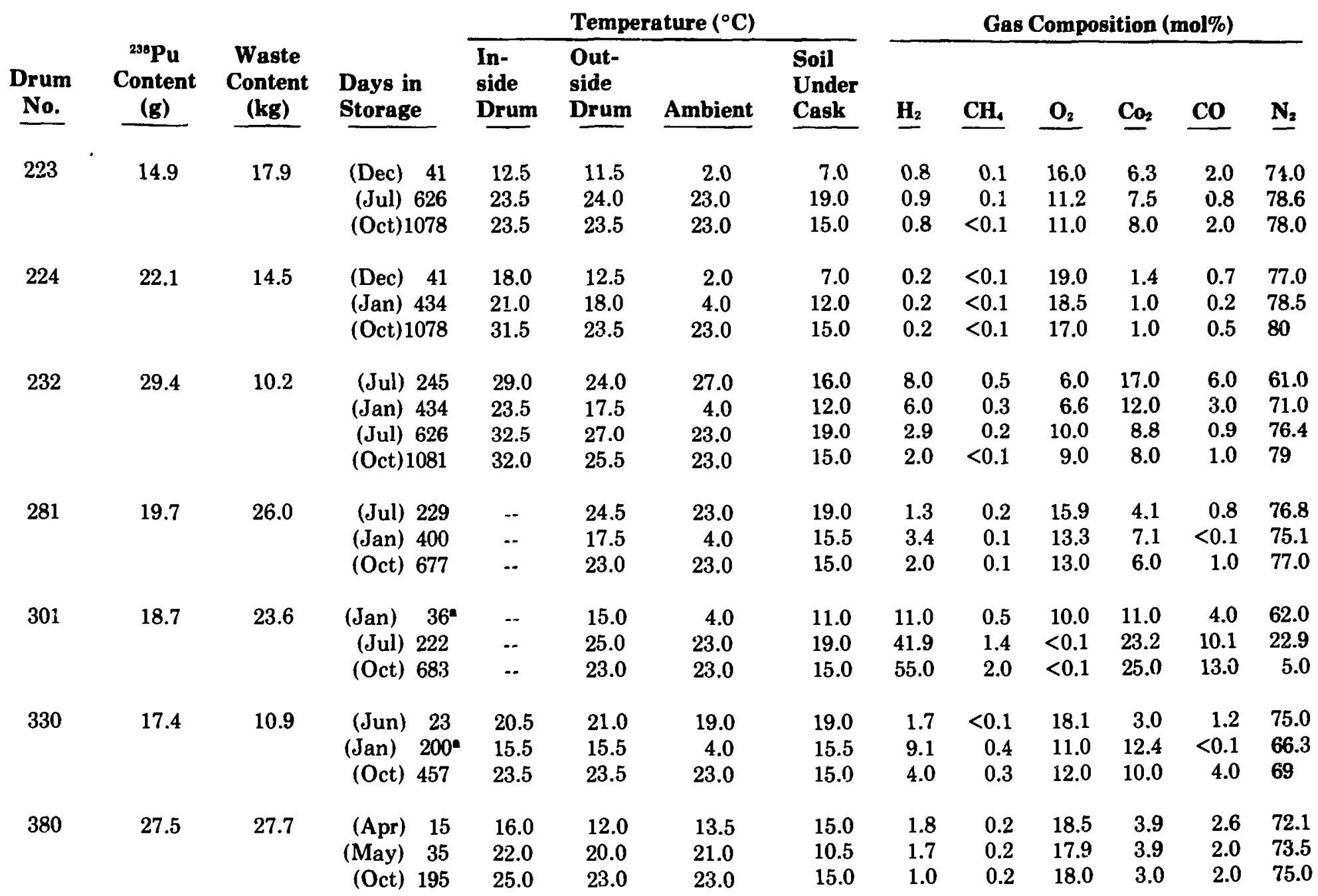

These samples were tested and found explosive. 
TABLEIX

SELECTED EXPLOSIMETER TESTS ON VARIOUS GAS MIXTURES

\begin{tabular}{|c|c|c|c|c|c|c|c|c|}
\hline \multirow{2}{*}{$\begin{array}{l}\text { Expl } \\
\text { Test } \\
\text { No. }\end{array}$} & \multicolumn{6}{|c|}{ Gas Composition } & \multirow[b]{2}{*}{ Explosible } & \multirow[b]{2}{*}{ Matrix } \\
\hline & $\underline{\mathbf{H}_{2}}$ & $\mathrm{CH}_{4}$ & $\underline{\mathbf{O}_{2}}$ & $\mathrm{CO}_{2}$ & $\mathrm{CO}$ & $\underline{\mathbf{N}_{2}}$ & & \\
\hline 53 & 4.1 & 0.2 & 19.2 & 2.5 & 1.5 & 71.6 & No & Cellulosics \\
\hline 52 & 4.3 & 0.1 & 9.8 & 0.1 & 0.2 & 36.6 & No & DuoSea ${ }^{\circledR}$ on vermiculite \\
\hline 59 & 4.5 & 0.2 & 19.1 & 2.8 & 1.4 & 71.1 & No & Cellulosics \\
\hline 49 & 5.0 & $<0.1$ & 11.7 & 2.0 & 0.9 & 43.3 & No & Water-soaked cellulosics \\
\hline 62 & 5.0 & 0.1 & 19.7 & 0.1 & 0.2 & 73.5 & No & DuoSeal $^{\mathcal{C}_{\text {on }}}$ vermiculite \\
\hline 50 & 5.2 & 0.2 & 14.8 & 2.5 & 0.8 & 55.4 & No & Cellulosics, plastics, rubbers \\
\hline 70 & 5.3 & 0.1 & 15.3 & 0.1 & 0.2 & 58.4 & No & DuoSea ${ }^{\circledR}$ on vermiculite \\
\hline 67 & 5.4 & $<0.1$ & 5.4 & 2.5 & 1.0 & 20.1 & No & Water-soaked cellulosics \\
\hline 66 & 5.5 & 0.2 & 5.7 & 2.8 & 1.9 & 21.1 & No & Cellulosics \\
\hline 68 & 5.5 & 0.2 & 7.1 & 3.2 & 1.5 & 27.0 & No & Cellulosics \\
\hline 51 & 5.5 & 0.2 & 19.6 & 0.1 & 0.3 & 73.5 & No & DuoSeal $\otimes_{\text {on }}$ vermiculite \\
\hline 48 & 5.6 & $<0.1$ & 6.8 & 1.9 & 0.9 & 24.4 & No & Water-soaked cellulosics \\
\hline 58 & 5.9 & 0.2 & 4.8 & 3.0 & 2.0 & 18.0 & No & Cellulosics \\
\hline 69 & 5.9 & $<0.1$ & 9.9 & $<0.1$ & 0.3 & 37.0 & No & Polyethylene \\
\hline 57 & 6.0 & $<0.1$ & 5.0 & 2.0 & 1.0 & 18.0 & No & Water-soaked cellulosics \\
\hline 60 & 6.0 & $<0.1$ & 9.8 & 2.5 & 1.1 & 36.9 & No & Water-soaked cellulosics \\
\hline 42 & 6.1 & 0.2 & 6.5 & 3.6 & 1.9 & 23.6 & Yes & Cellulosics \\
\hline 72 & 6.1 & 0.2 & 7.4 & 3.6 & 2.0 & 27.0 & Yes & Cellulosics \\
\hline 44 & 6.2 & $<0.1$ & 6.0 & 2.1 & 0.9 & 21.0 & No & Water-soaked cellulosics \\
\hline 46 & 6.3 & $<0.1$ & 6.7 & $<0.1$ & 0.3 & 24.3 & No & Polyethylene \\
\hline 74 & 6.3 & 0.2 & 7.3 & $<0.1$ & 0.1 & 27.8 & No & DuoSealOon vermiculite \\
\hline 71 & 6.4 & $<0.1$ & 18.7 & 2.9 & 1.0 & 70.0 & No & Water-soaked cellulosics \\
\hline 75 & 6.5 & 0.2 & 7.4 & 3.0 & 0.7 & 27.0 & Yes & Cellulosics, plastics, rubbers \\
\hline 45 & 6.6 & 0.2 & 6.5 & $<0.1$ & 0.2 & 24.1 & No & DuoSeal@on vermiculite \\
\hline 61 & 6.7 & $<0.1$ & 14.3 & $<0.1$ & 0.2 & 54.8 & No & Polyethylene \\
\hline 55 & 6.8 & $<0.1$ & 6.2 & 0.1 & 0.3 & 24.0 & Yes & Polyethylene \\
\hline 76 & 6.8 & 0.3 & 7.0 & 4.6 & 0.1 & 26.3 & Yes & Cellulosics \\
\hline 43 & 6.8 & 0.2 & 7.9 & 0.1 & 0.2 & 29.2 & Yes & DuoSeal ${ }^{\mathbb{}}$ on vermiculite \\
\hline 73 & 6.9 & $<0.1$ & 7.4 & 3.2 & 1.2 & 26.5 & Yes & Water-soaked cellulosics \\
\hline 40 & 6.9 & 0.3 & 9.0 & 6.0 & 2.0 & 34.0 & Yes & Cellulosics \\
\hline 56 & 7.0 & $<0.1$ & 6.4 & 3.0 & 1.0 & 24.0 & Yes & Water-soaked cellulosics \\
\hline 64 & 7.0 & 0.2 & 6.6 & 3.0 & 1.0 & 25.0 & Yes & Cellulosics, plastics, rubbers \\
\hline 47 & 7.1 & 0.3 & 6.9 & 5.4 & 2.0 & 25.2 & Yes & Cellulosics \\
\hline 41 & 7.3 & 0.2 & 7.0 & 4.0 & 1.0 & 26.0 & Yes & Cellulosics, plastics, rubbers, \\
\hline 78 & 7.6 & $<0.1$ & 6.1 & $<0.1$ & 0.1 & 22.2 & No & Polyethylene \\
\hline
\end{tabular}


TABLE IX (cont)

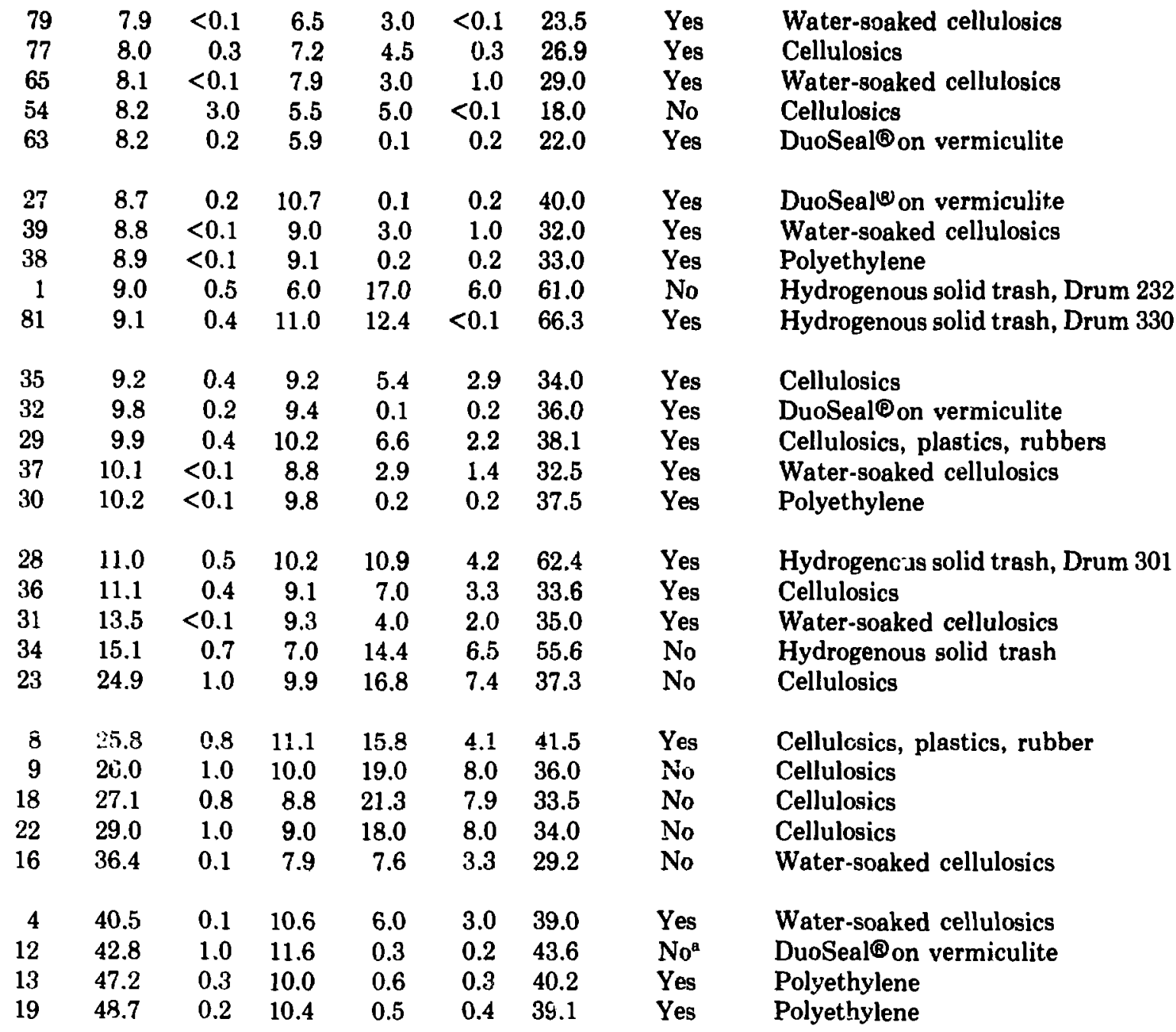

Apparently anomalous behavior.

The remarkable resistance of chlorinated polyvinyls and high-density cross-linked polyethylene to radiolytic attack undoubtedly accounts for their continued use in packaging TRUcontaminated waste. It is known" that PVC will eventually deteriorate, but if the waste previously is emplaced safely in a geologic formation, then the plastic will no longer be required as the primary containment. Clearly, the insignificant quantities of gas generated by radiolytic attack of these materials will not present problems. There was concern that if
PVC were incinerated before disposal, the quantity of $\mathrm{HCl}$ produced would create serious corrosion problems. Waste containing PVC has been burned in the LASL Controlled Air Incinerator; the offgas train has contained the $\mathrm{HCl}$ without problems, and no corrosion damage was noted in either stage of the incinerator. Obviously high-density polyethylene can be combusted easily if that is desired. It has also shown excellent resistance to attack (Table V) when contaminated with more than 400 times the amount of alpha that it could be exposed to at maximum 


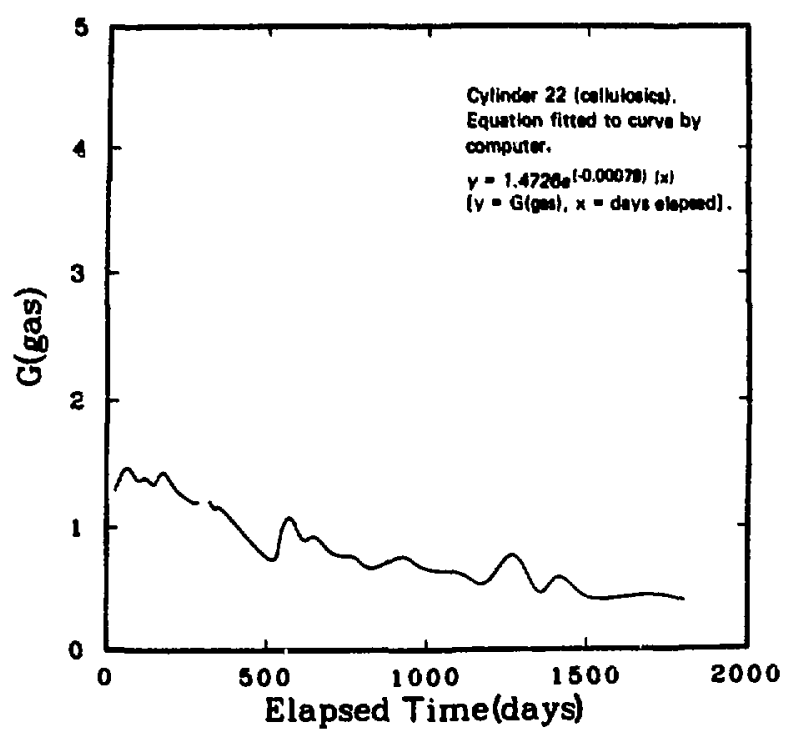

Fig. 20.

$G=$ gas molecules evolved per $100 \mathrm{eV}$.

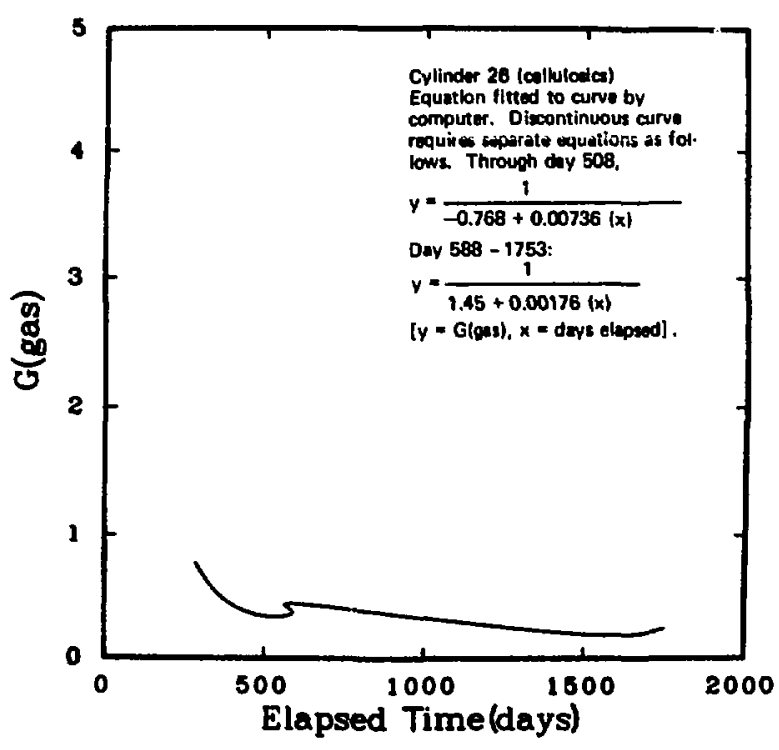

Fig. 21.

$G=$ gas molecules evolved per $100 \mathrm{eV}$.

TRU loading. Certainly it is reasonable to assume that its useful service life is more than enough to allow time for final disposal.

G(gas) values for additional laboratory experimental cylinders are shown in Figs. 22 through

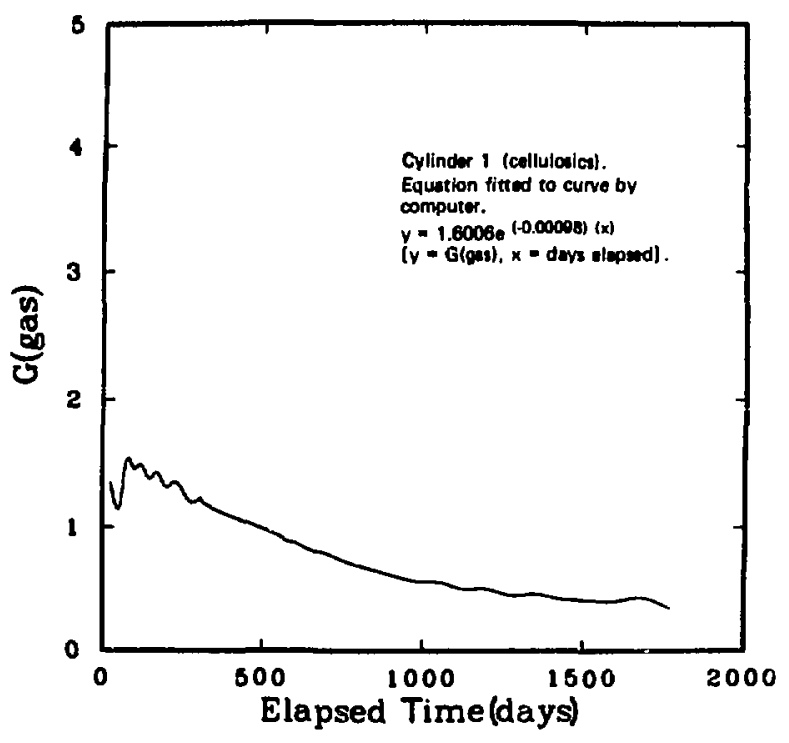

Fig. 22.

$G=$ gas molecules evolved per $100 \mathrm{eV}$.

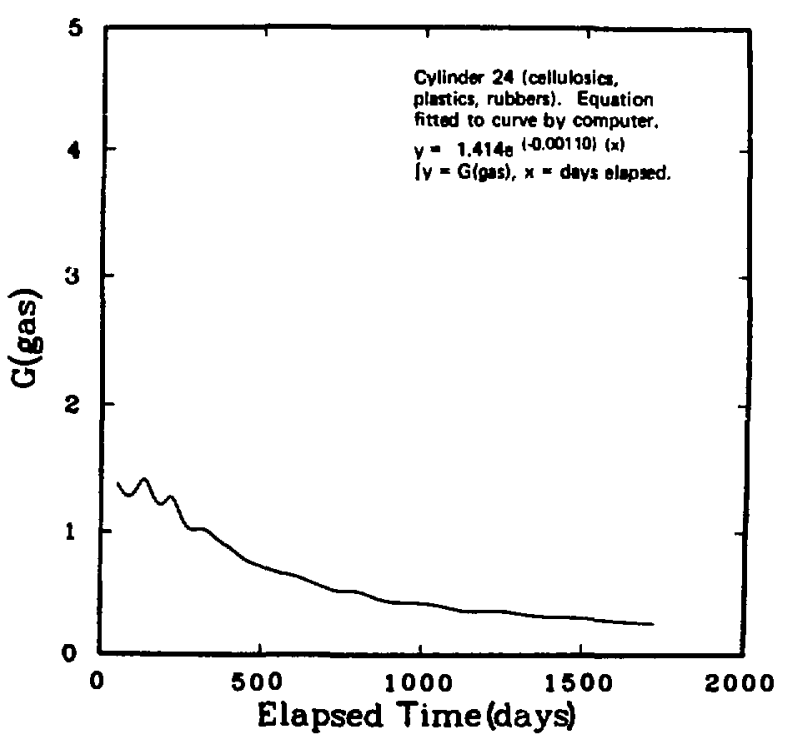

Fig. 23.

$G=$ gas molecules evolved per $100 \mathrm{eV}$.

28. $\mathbf{G}$ (gas) is defined as molecules of gas produced by each $100 \mathrm{eV}$ of energy deposited in the waste substrate. As previously specified, it will vary with the physical state of the contaminant and the identity of the waste. Each time one of the experimental 


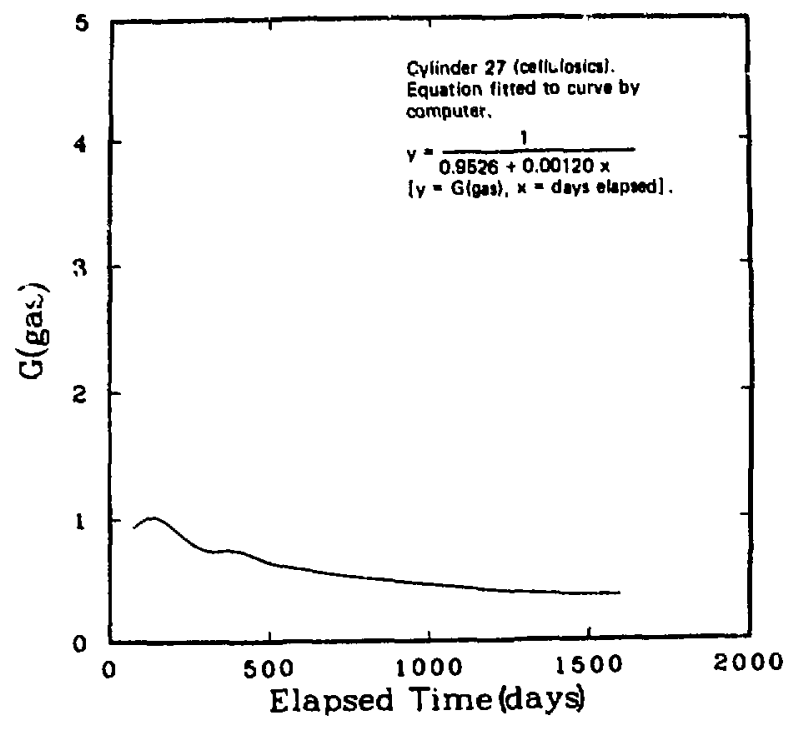

Fig. 24.

$G=$ gas molecules evolved per $100 \mathrm{eV}$.

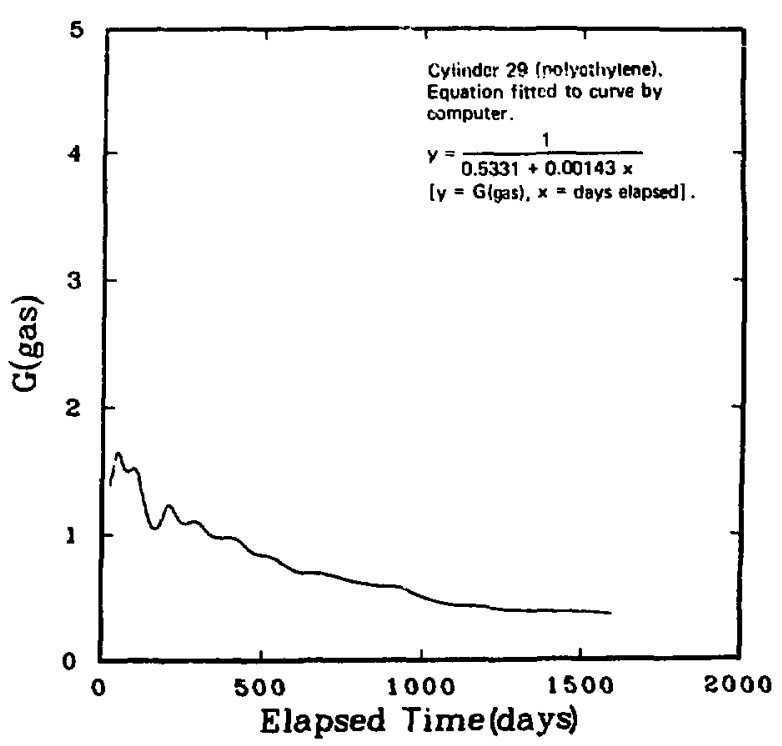

Fig. 25.

$G=$ gas molecules evolved per $100 \mathrm{eV}$.

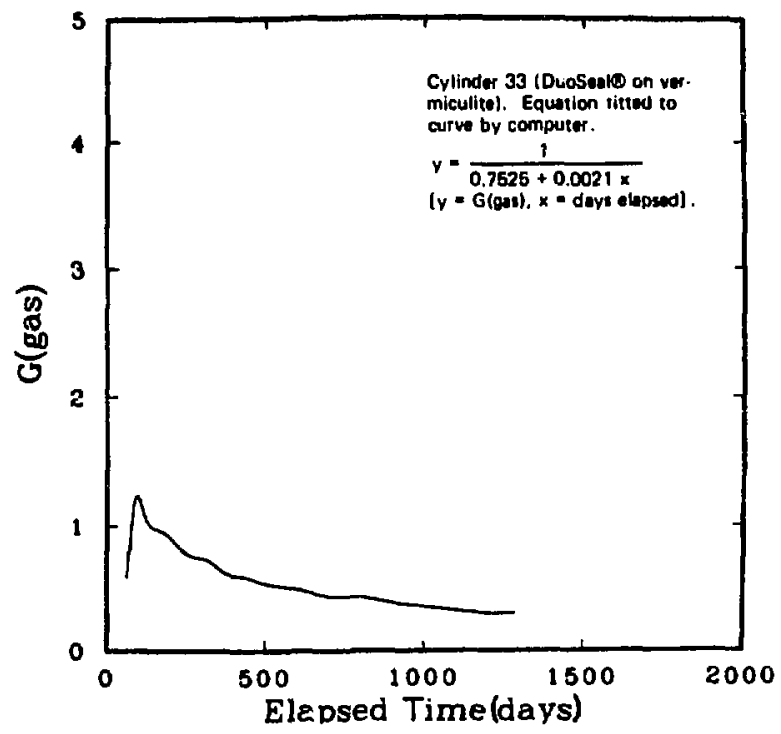

Fig. 26.

$G=$ gas molecules evolved per $100 \mathrm{eV}$.

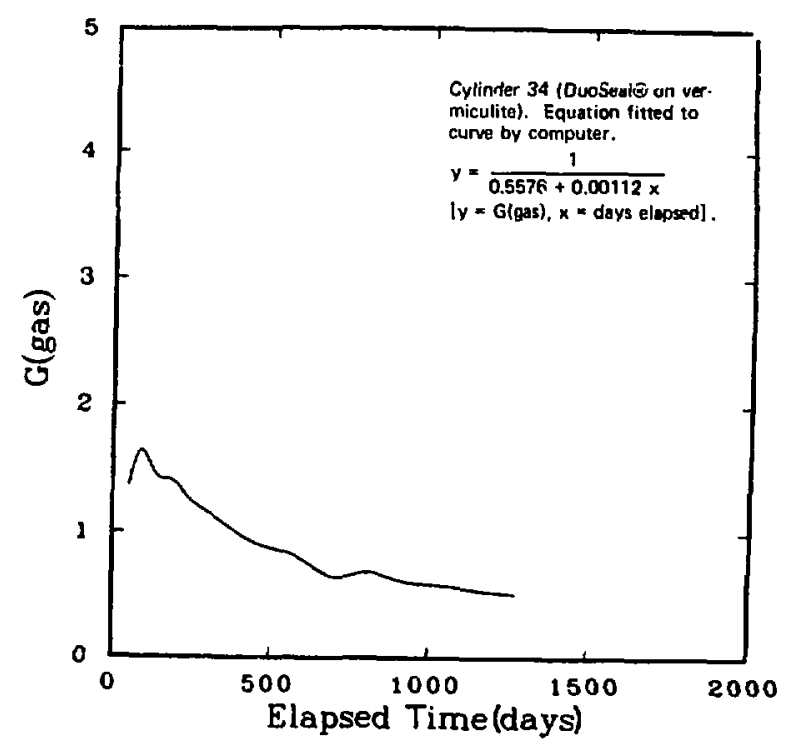

Fig. 27.

$G=$ gas molecules evolved per $100 \mathrm{eV}$. 


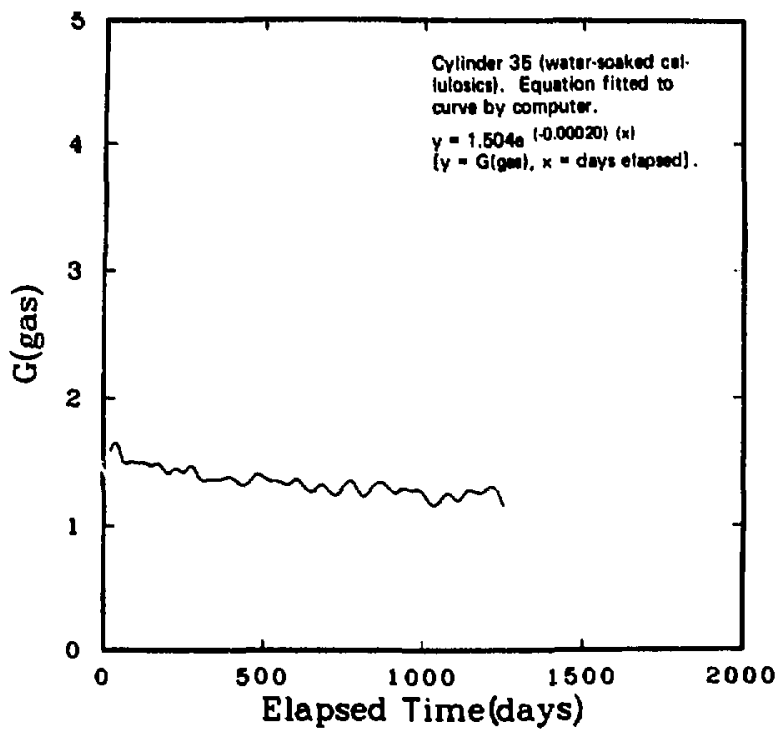

Fig. 28.

$G=$ gas molecules evolved per $100 \mathrm{eV}$.

cylinders was sampled, the $\Delta \mathrm{P}$ was converted to gas volume using a formula derived from the ideal gas law

(V) $(\Delta \mathrm{P})$

$1206(\mathrm{~T} \cdot \mathrm{k})\left(\mathrm{psi}-\mathrm{cm}^{2}\right) /($ mole K $)$

where $\mathrm{V}=$ effective volume of cylinder.

$\mathrm{G}$ (gas) was computed by

$100\left(\mathrm{mM}\right.$ gas) $\left(6.02 \times 10^{25}\right) /(\mathrm{eV}$ per day) (days).

As previously described, the rate of gas formation decreased with time. Clearly, decrease in G(gas) was directly proportional. Figure 22 shows the G(gas) curve for Cylinder 1, which contained dry cellulosics contaminated with $62 \mathrm{mg}{ }^{2 \mu} \mathrm{Pu}$. This curve represents 38 data points. In other words, it pressurized to $\sim 110 \mathrm{kPa} 38$ times in $4.9 \mathrm{yr}$. It reached full scale the first time in 24 days; most recently it required 91 days. The $\mathrm{G}$ (gas) computed for the first sample was 1.35 , the highest value was 1.52 , and the most recent was 0.34 . Note that the shape of the curve is typical of the results cuserved for most of the experimental cylinders-the value decreases initially, then increases, then begins a slow, steady decline. By using the equation derived from the data points for a specific curve, it is possible to extrapolate the gas production for that specific contaminated waste under those specific conditions to any desired time.

Cylinder 27 (Fig. 24) is of interest because it was contaminated with $31 \mathrm{mg}$ of ${ }^{288} \mathrm{Pu}$ as the chloride. This medium-level contamination generated less gas initially; it took 72 days to pressurize to full scale, and the $G$ (gas) was 0.93 . At $4.5 \mathrm{yr}$, after pressurizing 12 times, it required 188 days to pressurize for the 13th time, and the $G$ (gas) was 0.36 , compared to 0.34 for Cylinder 1 at $4.9 \mathrm{yr}$. The contaminant for this latter cylinder was $62 \mathrm{mg}{ }^{22} \mathrm{Pu}$ as the nitrate. The nitrate form gives a higher gas yield initially. This was not believed to be significant because, in contaminated waste exposed to air, the plutonium is converted to oxide in approximately 1 month. ${ }^{\text {ss }}$

The amount of gas generation from polyethylene (Fig. 25) is very similar to that from cellulosics (Fig. 22). The gas composition is significantly different (compare Figs. 10 and 11); the polyethylene produces almost all $\mathrm{H}_{2}$. Cylinders 33 and 34 (Figs. 26 and 27) contain oil sorbed on vermiculite. Each was contaminated with ${ }^{298} \mathrm{Pu}$ as the oxide, the former with $62 \mathrm{mg}$ and the latter with half that amount. The finely divided oxide was dispersed thoroughly in the oil before it was added to the vermiculite. After the sorption, no free liquid remained, so the $\mathrm{PuO}_{2}$ could not settle out. The strongly contaminated sample required 28 days to reach full pressure $(\sim 110 \mathrm{kPa})$ the first time; the $\mathrm{G}$ (gas) was 1.22. In $3.6 \mathrm{yr}$, this cylinder pressurized 20 times, producing $212.5 \mathrm{mM}$ of gas. The final pressurization took 104 days; the $\mathrm{G}$ (gas) was 0.30 . The mediumlevel contamination sample took 49 days to reach full pressure the first time; the $G$ (gas) was 1.37 . It pressurized 16 times in $3.7 \mathrm{yr}$, producing $171.6 \mathrm{mM}$ of gas. The final pressurization required 121 days; the $\mathrm{G}$ (gas) was $\mathbf{0 . 5 2}$. The remarkable efficiency of half as much contamination in the same quantity of substrate is not understood. Cylinder 35 (Fig. 28) contained the most efficient gas producer of all- 62 
$\mathrm{mg}{ }^{238} \mathrm{Pu}$ on $52.5 \mathrm{~g}$ cellulosics soaked with $52.5 \mathrm{~g}$ $\mathrm{H}_{2} \mathrm{O}$. First pressurization, 21 days, $\mathrm{G}$ (gas) 1.59; second time, 21 days, $G$ (gas) 1.65 , which is the highest $G$ value. The sample has pressurized 48 times in $3.5 \mathrm{yr}$, producing $533.2 \mathrm{mM}$ gas. The latest pressurization required 27 days; the $\mathrm{G}$ (gas) was 1.16. There seems little doubt that the $\mathrm{H}_{2} \mathrm{O}$, in addition to the cellulose, is producing gas from alpha attack. These findings do not agree with Kazanjian's. ${ }^{8}$

The data from the ${ }^{299} \mathrm{Pu}$ and ${ }^{298} \mathrm{Pu}$-contaminated waste retrievably stored at the LASL disposal area show there is no radiolytically generated gas problem in the ${ }^{239} \mathrm{Pu}$ interim storage. The drums that were opened (Table VI) showed some evidence of corrosion on the inside (Fig. 29), but the 0.13-mm polyethylene bags of waste were intact until the:" were ripped open intentionally (Fig. 30 ). The individual $0.3-\mathrm{mm}$ PVC bagouts inside were in good shape as far as the PVC was concerned, but the masking tape closures had failed. Figure 31 shows the contrast in the resistance of the two materials to what was probably a combination of chemical and radiolytic attack. The spin-off from this evidence was a decision to replace the masking tape with vinyl plastic tape for future bagout closures. The deterioration of the contents of these bagouts resembled that shown in Fig. 19. If this waste were to be processed. the oldest waste probably is potentially the most hazardous because it is the most degraded and the least well categorized.

Containers of ${ }^{238} \mathrm{Pu}$-contaminated waste definitely are generating gases from radiolytic attack. Their contents degrade rapidly from the alpha attack, and also from the heat $(\sim 0.5 \mathrm{~W} / \mathrm{g})$ given off by the contaminant. If an effort is made to reprocess this material, extreme caution must be exercised to prevent spark generation before the gaseous contents of these drums are analyzed and/or replaced with inert gas. Scrupulous hand ${ }_{11}$ g will be required to avoid dispersing the finely divided, low-density degradation products prasent. Each cask (containing two $115-\ell$ drums) weighs in excess of $1140 \mathrm{~kg}$. Moving them will be a difficult and expensive job. They are isolated on a high and dry mesa in volcanic ash (tuff), which never has a moisture content $>3 \%$. It is my opinion that this storage in an already contaminated, dedicated waste disposal area would be satisfactory for many years.

The following conclusions can be drawn from the explosimeter data. If the $\mathrm{H}_{2}$ content of the gaseous

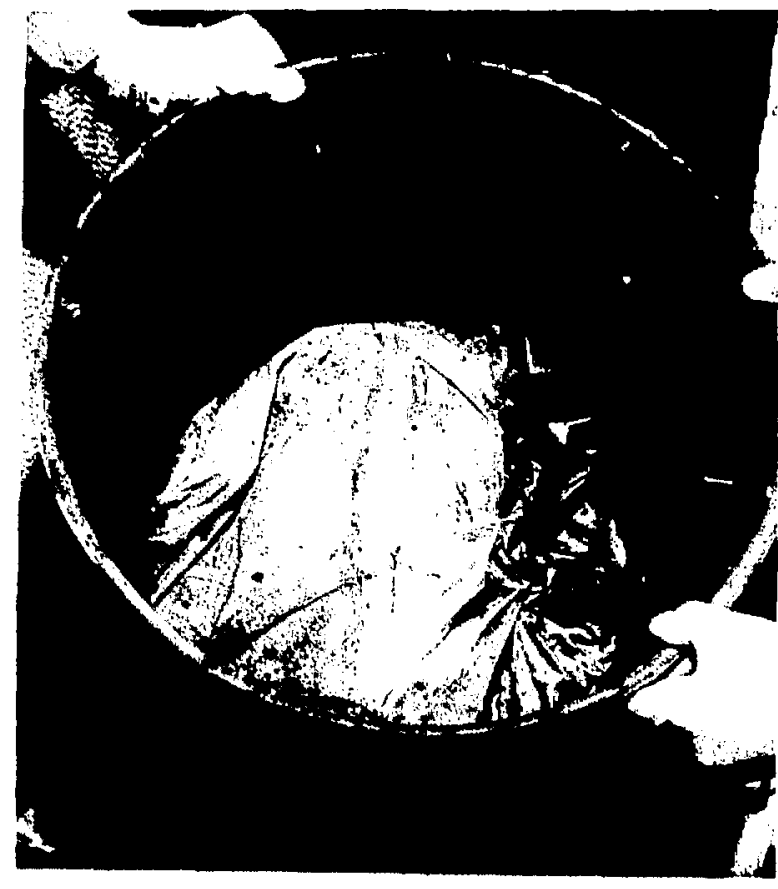

Fig. 29.

Opened waste drum showing polyethylene bag intact.

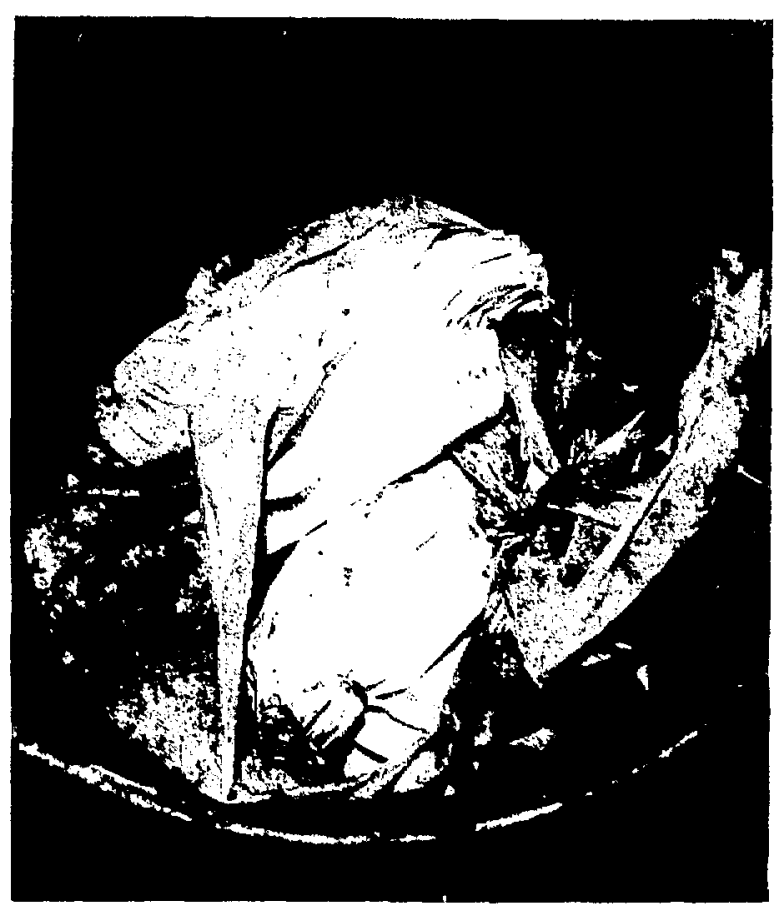

Fig. 30.

Individual bags of waste. 


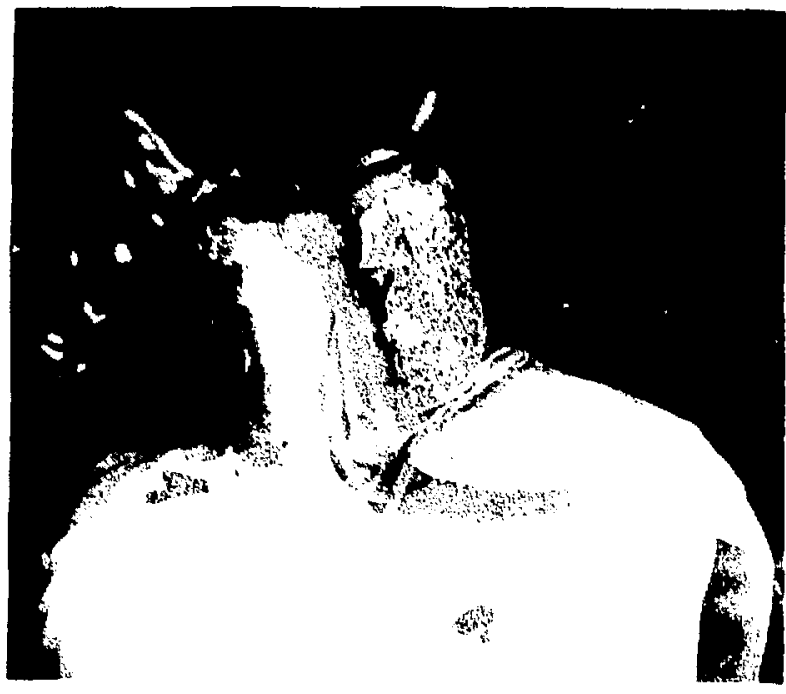

Fig. 31 .

Contrast in resistance of materials.

mixture is 6 mol\% or below, it probably is not explosible. A gaseous mixture with relatively high $\mathrm{H}_{2}$ content and low $\mathrm{O}_{2}$ may not be explosible, as shown by tests $9,16,18$, and 23 (Table IX). A potential hazard exists because of the generation of a combustible gas mixture in some of these drums, but it appears to be a problem that diminishes with time, and in no case has it been demonstrated to be insurmountable for near-surface storage. Because of the likelihood of air diffusion into any storage drum, all drums of ${ }^{238} \mathrm{Pu}$-contaminated hydrogenous waste in interim storage must be considered potentially explosive until their gaseous contents have been analyzed and/or replaced with inert gas. We reiterate the importance of this consideration when recovering or reprocessing ${ }^{230} \mathrm{Pu}$-contaminated interim storage waste. A drum-sampling device ${ }^{10}$ has been developed and successfully used, repeatedly, to sample the gaseous contents of waste drums without exposure to air.

The program for studying gas generation by radiolytic attack of hydrogenous materials is continuing, with special emphasis on conditions which are anticipated in the Waste Isolation Pilot Plant deep geologic disposal.

\section{ACKNOWLEDGMENT}

I appre iate the help of coworker Stanley Kosiewicz in collecting and interpreting some of the tata used in this report, and the cooperation of numerous coworkers in LASL groups CMB-1 and H.7.

\section{REFERENCES}

1. "AEC Waste Management and Transportation Division, Immediate Action Directive," AEC Appendix 0511, Part 1, paragraph 23a (1970).

2. US Atomic Energy Commission, AEC Manual, Chapter 0511-01, paragraph 44d (1978).

3. Karen Pashman, Los Alamos Scientific Laboratory, unpublished report, 1973.

4. D. E. Michels, Aerojet Nuclear Company, unpublished report, 1974.

5. J. W.T. Spinks and R. J. Woods, An Introcuction to Radiation Chemistry (J. Wiley \& Sons, New York, 1964).

6. M. E. McLain, "Visit to SRL/SRP," Los Alamos Scientific Laboratory internal document (April 2, 1974).

7. Savannah River Quarterly Report, "Waste Management," E. I. duPont de Nemours \& Co.. Savannah River Laboratory report DPST-74125-1, pp. 49-51 (1974).

8. A. Kazanjian, "Radiolytic Gas Generation in Plutonium Contaminated Waste Materials," Rockwell International, Atomics International Division, Rocky Flats Plant report RFP 2469 (October 1976).

9. R. Mulkin, "Characterization of Transuranic Solid Wastes from a Plutonium Processing Facility," Los Alamos Scientific Laboratory report LA-5993-MS (June 1975). 
10. DRUM SAMPLING DEVICE. LASL Drawings No. 26Y199057-1,2,3 (1975).

11. A. R. Kazanjian and D. R. Horrell, "Thermal and Radiation Stability of Polyvinyl Chloride," Dow Chemical USA, Rocky Flats Division report RFP-1924 (September 1972).

12. M. A. Molecke, "Waste Isolation Pilot Plant Transuranic Wastes Experimental Charac- terization Program: Executive Summary, "Sandia Laboratories report SAND 78-1356 (1978).

13. C. S. MacDougall and A. Barry, "Alpha-Waste Repository Program (A412) Report for the Period 11-1-72 to 2-28-73," Group CMB-1, Los Alamos Scientific Laboratory internal document, pp. 6,7 (1973). 